\title{
Transient hydrographic and chemical conditions affecting microplankton populations in the coastal transition zone of the Iberian upwelling system (NW Spain) in September 1986
}

\author{
by C. G. Castro ${ }^{1}$, X. A. Alvarez-Salgado ${ }^{1}$, F. G. Figueiras ${ }^{1}$, F. F. Perez ${ }^{1}$ and F. Fraga ${ }^{1}$
}

\begin{abstract}
The coastal transition zone and adjacent continental shelf of the Iberian upwelling system was studied in September 1986, during the seasonal transition from upwelling-favored to downwellingfavored winds. The most striking features in the coastal transition zone were: (1) a poleward flow of high salinity Eastern North Atlantic Central Water (subtropical) off the Rías Baixas (Galician western coast); and (2) an anticyclonic eddy off Cape Ortegal (Galician northern coast). Chemical and biological similarities between both structures, clearly different from the surrounding oceanic waters, suggest that the eddy was an isolated and aged parcel of water originating from the poleward flow. The continental shelf was characterized by: (1) outwelling of chlorophyll-rich waters from the four large coastal embayments (the "Rías Baixas") in the western coast and; (2) an upwelling front off the northern coast. The coexistence of opposite hydrographic structures, as the poleward flow and the upwelling front, was the consequence of transitional wind conditions in September-October, and we hypothesized transitional conditions to be crucial for the development of the eddy. Both the poleward flow and the eddy precluded the shelf-edge exchange of microplankton populations developed over the shelf, leading to massive in situ sedimentation and subsequent nutrient mineralization over the shelf.
\end{abstract}

\section{Introduction}

Seasonality of surface currents in the Iberian coastal transition zone (CTZ) has been related to seasonal changes in wind stress along the cuast, caused by the large-scale climatology of the NE Atlantic (Wooster et al., 1976; Fiúza et al., 1982; Blanton et al., 1987; Bakun and Nelson, 1991). From May to October, the Azores high pressure cell is located in the central North Atlantic and the intensity of the Greenland low diminishes, provoking the dominance of northerly winds. They originate wind-driven upwelling (Fraga, 1981; Fiúza, 1983; McClain et al., 1986), and associated structures such as upwelling centers and filaments (Haynes et al., 1993) along the Iberian coast. Enhancement of the export of coastal waters to the open ocean occurs during this season.

1. CSIC, Instituto de Investigacions Mariñas, Eduardo Cabello 6, E-36208 Vigo, Spain. 
From October to April, southerly winds prevail since the Azores high moves off NW Africa and a deep low is located off SE Greenland. This situation favors the development of the poleward flow of warm and salty water. Satellite images demonstrate water inflow along the Iberian slope. Evidences of a poleward surface current have been found as south as Cape Saõ Vicente (Ambar et al., 1984; Frouin et al., 1990), which penetrates as north as the Armorican shelf (Pingree and Le Cann, 1990), being clearly constrained by topography. The poleward flow, a relatively low-energy phenomenon with surface currents of $0.1-$ $0.2 \mathrm{~cm} \cdot \mathrm{s}^{-1}$ (Haynes and Barton, 1990; 1991), dominates the CTZ precluding shelf-ocean exchange.

The most energetic features are small mesoscale eddies observed by Advanced Very High Resolution Radiometer (AVHRR), as in other eastern boundary regions (Wooster and Reid, 1963). Wyrtki et al. (1976) gave the first description of eddy activity in the area. A series of hydrographic surveys consistently showed evidence of mesoscale eddies in the computed dynamic topographies (Fruchaud, 1975; Fruchaud-Laparra et al., 1976a,b). Dickson and Hughes (1981) provided the first synoptic description of mesoscale eddy activity over the Biscay abyssal plain, by means of AVHRR. They pointed out their role in the transport of heat and salt, in spite of their limited size compared with eddies on the flanks of the Mid Atlantic Ridge. Further studies about eddy activity in this eastern boundary region were conducted by Pingree and Le Cann (1990; 1992a,b). These authors show how warm water from the slope current is injected into deep water regions of the Bay of Biscay to form anticyclonic eddies. These anticyclonic eddies, that they coined as swoddies (Slope water ocean eddies) tend to result from jet-like extensions of the slope current, associated with particular topographic features (Pingree, 1994). Recurrent eddies were found off Ferret Canyon, Torrelavega Canyon and Cape Ortegal.

Studies focused on chemical and biological (phytoplankton composition) conditions in the Iberian upwelling system are scarce. The recurrent upwelling center off Cape Finisterre (northern coast) and the freshwater outwelling from the Rías Baixas (western coast) have been surveyed, and briefly characterized (Fraga, 1981; Alvarez-Salgado et al., 1993; Tenore et al., 1995). Large diatoms are associated with upwelling structures while small cells (flagellates and dinoflagellates) are found under stratification conditions (Estrada, 1984; Varela et al., 1991). Very few observations are related with the presence of a poleward flow of high salinity water. Fernández et al. (1991) in the Bay of Biscay found small flagellates and dinoflagellates with no diatoms associated with a spring high salinity intrusion.

In September 1986, the oceanography group of the Instituto Investigacións Mariñas occupied the Galician coast from Cape Peñas to River Miño, during the GALICIA-IX cruise. Two large domains were found, the continental shelf and the CTZ. The aim of this paper is to describe them from the hydrographic, chemical and biological point of view. Special attention is paid to the CTZ, where a poleward current off the Rías Baixas and a surface eddy off Cape Ortegal are the main features. Influence of these structures on the shelf regime and their biological consequences will be shown. 


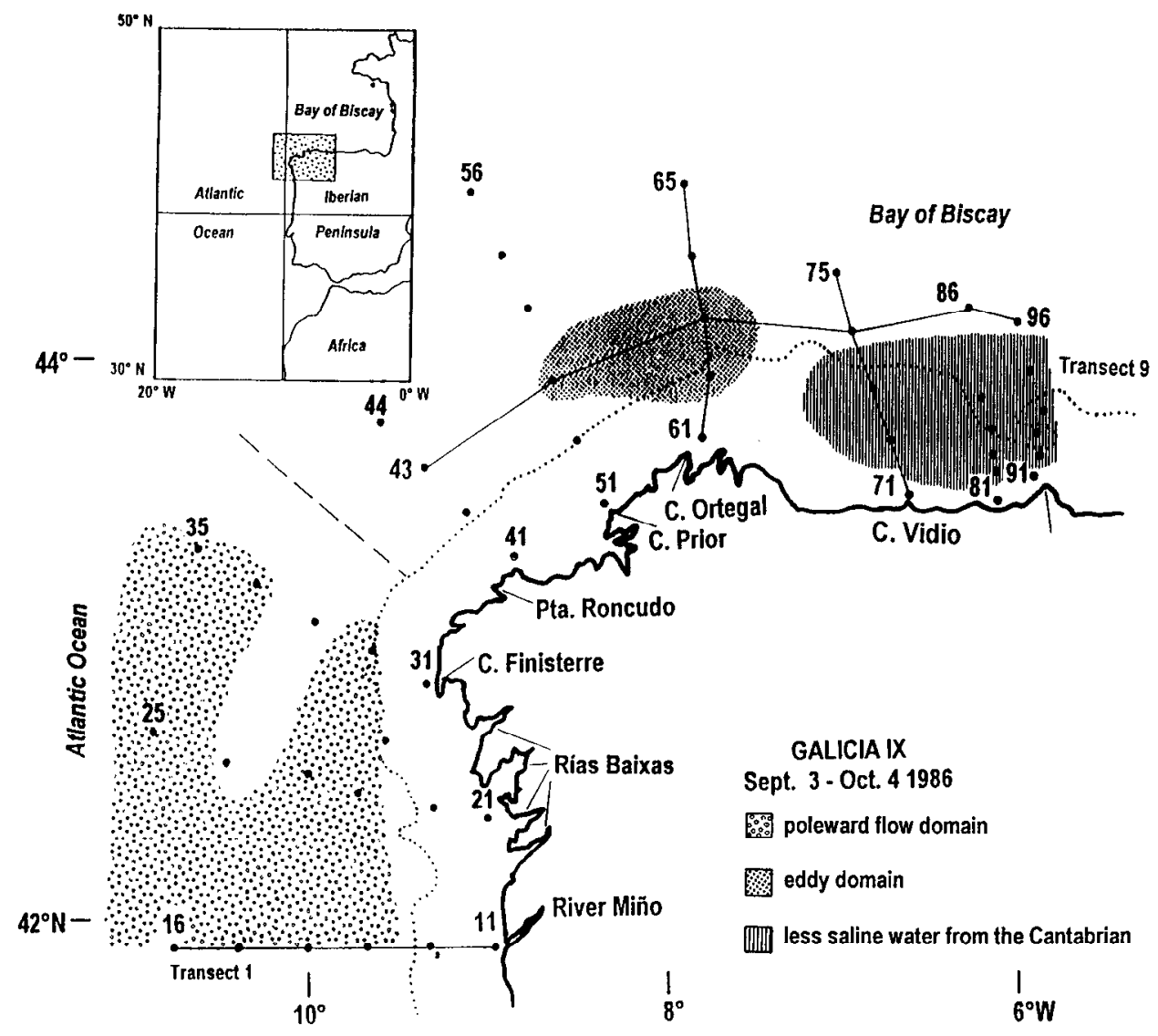

Figure 1. Map of the NW Iberian Peninsula, with the stations surveyed during the GALICIA-IX cruise. Solid lines, vertical distributions presented in the following. At each section, numbers correspond to the extreme stations. The main hydrographic features found during the cruise are presented. Dashed line, discontinuity in the sampling program (transects 9 to 4 were sampled from 5 to 12 September and transects 3 to 1 were surveyed from 24 to 27 September 1986). Dotted line, $200 \mathrm{~m}$ isobath.

\section{Materials and methods}

GALICIA IX cruise was carried out aboard $R / V$ García del Cid, from September 4 to October 3, 1986. The region studied was from $42 \mathrm{~N}$ to $44 \mathrm{~N}$, and from $6 \mathrm{~W}$ to $11 \mathrm{~W}$ (Fig. 1). Forty-six stations were occupied along nine transects perpendicular to the coast, starting off Cape Peñas (transect 9) and ending off the River Miño (transect 1). Strong southwesterly winds on September 12, prevented us from continuing surveying after completion of transect 4. Transects 1 to 3, off the Rías Baixas, were occupied from September 24 on.

Samples were taken with 0.7 and 5 liter Niskin bottles, attached with Watanabe thermometers, at selected depths from surface to $2000 \mathrm{~m}$. Subsamples were taken to 
determine salinity, nutrients, oxygen and pH. Subsamples for chlorophyll- $a$ (Chl $a)$ and microplankton determinations were taken from surface to $200 \mathrm{~m}$, but microplankton was sampled only in transects 1 to 7. Salinity was calculated using Eq. (6) of UNESCO (1981) from conductivity measurements with an AUTOSAL 8400A, calibrated with "Copenhagen Standard Water." Nutrient concentrations were measured on board by Technicon AAII SFA systems, according to Hansen and Grasshoff (1983) with some improvements (Mouriño and Fraga, 1985). Chl $a$ was measured after 90\% acetone extraction in a 10,000 R Turner fluorometer (Yentsch and Menzel, 1963). Microplankton samples were preserved in Lugol's iodine and sedimented in composite sedimentation chambers. The sedimented volume (25-100 $\mathrm{ml}$ ) depended on the chlorophyll concentration of the sample. When possible, organisms were identified to the species level using Utermöhl (1958) technique. Two transects at $\times 400$ and $\times 250$ were used to count the small species. The larger forms were counted from the whole slide at $\times 100$ magnification. Deeper water samples were only counted when $\mathrm{Chl} a$ was detectable.

Principal component analysis (PCA) was used to reduce and simplify the information included in the list of species abundance, to define the microplankton assemblages, and to determine changes in species composition. The analysis was carried out using the correlation matrix of species abundance where the abundance was transformed to log $(X+1)$ and $X$ represents the number of individuals per $100 \mathrm{ml}$ of seawater. In order to eliminate double zeros in the matrix, species which were present in at least 10,20 and $30 \%$ of the samples were processed. The PCA made with the species present in at least $10 \%$ of the samples showed the greatest separation in communities, while still retaining the species belonging to the coastal domain. This criterion gave a starting matrix of 78 species and 324 samples.

Upwelling index, $I_{w}$, was calculated at $43 \mathrm{~N}, 11 \mathrm{~W}$ (150 km off Cape Finisterre) using geostrophic winds deduced from surface pressure charts, provided three times per day. The vectors were multiplied by 0.7 and cyclonically rotated by $15^{\circ}$ to estimate the surface wind velocity (Bakun, 1973). The parallel $(\|)$ and perpendicular $(\perp)$ components to the western Iberian coast were computed from the equations

$$
\begin{aligned}
I_{W \|} & =\frac{\rho_{a} \cdot C \cdot|\mathbf{V}|}{f \cdot \rho_{w}} \cdot V_{\|} \\
I_{W \perp} & =\frac{\rho_{a} \cdot C \cdot|\mathbf{V}|}{f \cdot \rho_{w}} \cdot V_{\perp}
\end{aligned}
$$

Where $\rho_{a}$ is the density of air, $1.21 \mathrm{~kg} \cdot \mathrm{m}^{-3}$ at $19^{\circ} \mathrm{C} ; C$ is an empirical drag coefficient (dimensionless), 1.3 $10^{3}$ according to Hidy (1972); $f$ is the Coriolis parameter, 9.95 . $10^{-5} \mathrm{~s}^{-1}$ at $43^{\circ}$ latitude; $\boldsymbol{\rho}_{w}$ is the density of seawater, $\sim 1026 \mathrm{~kg} \cdot \mathrm{m}^{-3},|\mathbf{V}|$ is wind speed; and $V_{\|}$and $V_{\perp}$ are components of wind speed, parallel and perpendicular to the coast. Positive values of the parallel component indicate upwelling off the Rías Baixas, 
while positive values of the perpendicular component indicate upwelling in the Cantabrian Sea.

\section{Results}

a. The wind regime. In the Iberian upwelling, transition from predominantly northerly (upwelling favorable) to predominantly southerly (downwelling favorable) winds use to occur by September-October (Wooster et al., 1976; Blanton et al., 1984; Bakun and Nelson, 1991). Figure 2 shows such a transition: for the first week of September northerly winds prevailed, while during the second week southerly winds were continuously blowing. From mid-September, predominantly northerly winds occurred again. The high positive covariance between $I_{W \|}$ and $I_{W \perp}, r=0.70$, led to simultaneous upwelling in both coasts in response to the wind field.

Daily averaged local winds were obtained from an automatic recorder at the Cape Finisterre Meteorological Observatory. Upwelling index calculated from these winds are more local and less damped, compared with those obtained from geostrophic winds. Comparison of both sets of upwelling indices aided us to establish the current state, transitional or steady, of nutrients and phytoplankton distributions during the sampling dates (Small and Menzies, 1981).

$I_{W \mid}$ calculated from geostrophic and local winds have been regressed $(r=0.73)$ and the residuals represented in Figure 2c. Steady-state conditions can be assumed for dates within \pm 1 standard deviation (STD) of the residual mean (Small and Menzies, 1981). Consequently, only on September 3,17 and 18, transitional distributions could have been observed. On the other hand, during the sampling dates (September 5 to 12 and 24 to 27) steady-state distributions were found. $I_{W \perp}$, calculated from actual winds, was useless because of strong disturbances by surrounding topography at Cape. Finistere.

b. Hydrographic domains and microplankton assemblages. During the GALICIA-IX cruise, two broad domains were discerned: the continental shelf and the CTZ (Fig. 1). The CTZ was characterized by the presence of two prevailing structures. Off the Rías Baixas, a poleward-flowing high salinity water was observed and to the north, an anticyclonic eddy off Cape Ortegal was the most striking feature. The continental shelf was divided into two domains; off the Rías Baixas, where "outwelling" from these four large embayments prevailed (Fraga, 1981; López-Jamar et al., 1992; Tenore et al., 1995) and to the north of Cape Finisterre, where intense upwelling occurred. A thermohaline and chemical charactercitization of the different domains and interaction among them will be presented, as well as the associated microplankton assemblages.

Three principal components, explaining $30 \%$ of total variance in the original data, resulted from the Principal Component Analysis (PCA) and defined the main microplankton assemblages. Principal component 1 (PC 1) distinguishes between one assemblage in which several dinoflagellates and ciliates had the highest positive loads and another where diatoms and two dinoflagellates (Triadinum polyedricum and Prorocentrum minimum) 


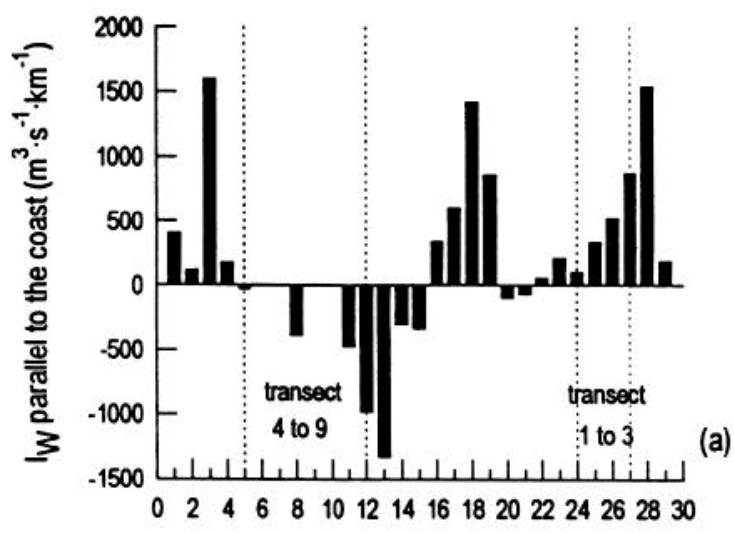

Day (September 86)

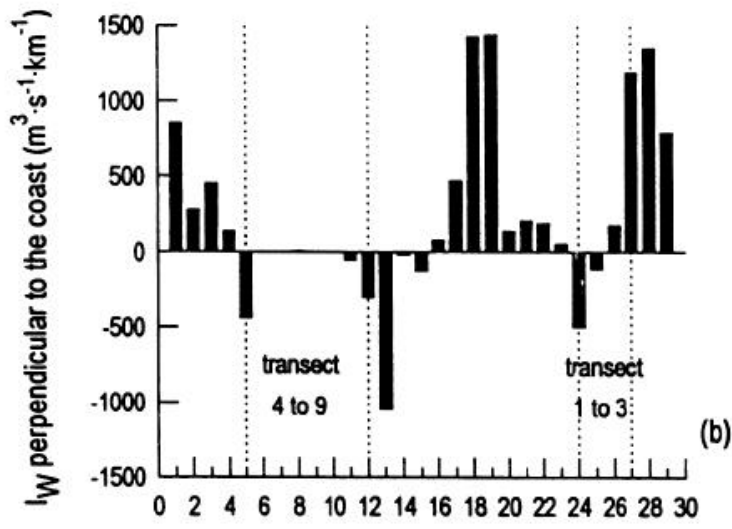

Day (September 86)

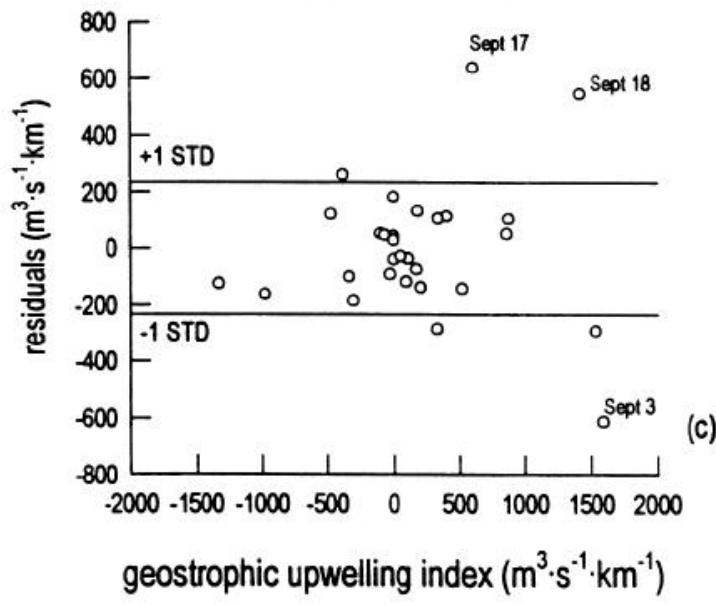

Figure 2. Daily averaged Bakun's upwelling index $\left(\mathrm{m}^{3} \cdot \mathrm{s}^{-1} \cdot \mathrm{km}_{\text {coast }}{ }^{-1}\right)$ during September 1986. Parallel (a); and perpendicular (b) components to the west coast of the Iberian Peninsula. (c) Plot of residuals from the regression between upwelling indices (parallel component) calculated with actual winds at the Cape Finisterre Meteorological Observatory and geostrophic winds at $43 \mathrm{~N}$, $11 \mathrm{~W} v s$. the upwelling index with the geostrophic winds. 
Table 1. Correlation coefficients of the species and taxa selected for Principal Component Analysis (PCA) with the first principal component. The PCA made with the species present in at least $10 \%$ of the samples showed the greatest separation in communities, while still retaining the species belonging to the coastal domain. Only those species with higher correlations $(>0.20)$ are given. The species were grouped in diatoms (Diat.); dinoflagellates (Dinof.); flagellates other than dinoflagellates (Flag.) and ciliates (Cil.).

\begin{tabular}{|c|c|c|}
\hline Group & Taxon & $\mathrm{PC} 1$ \\
\hline Dinof. & Gymnodinium simplex & 0.717 \\
\hline Flag. & Heterosigma carterae & 0.693 \\
\hline Flag. & Leucocryptos spp. & 0.692 \\
\hline Cil. & Oligotrichous ciliates (large, $>>30 \mu \mathrm{m}$ ) & 0.669 \\
\hline Dinof. & Cochlodinium helix & 0.669 \\
\hline Dinof. & Amphidinium flagellans & 0.624 \\
\hline Cil. & Oligotrichous ciliates (medium, $30-60 \mu \mathrm{m}$ ) & 0.620 \\
\hline Dinof. & Torodinium robustum & 0.593 \\
\hline Cil. & Oligotrichous ciliates (small, $<30 \mu \mathrm{m}$ ) & 0.593 \\
\hline Cil. & Salpingacantha $\mathrm{sp}$ & 0.570 \\
\hline Dinof. & Gyrodinium fusiforme & 0.549 \\
\hline Dinof. & Gymnodinium nanum & 0.546 \\
\hline Dinof. & Ceratium fusus & 0.546 \\
\hline Flag. & Solenicola setigera & 0.522 \\
\hline Dinof. & Scrippsiella trochoidea & 0.512 \\
\hline Cil. & Strombidium strobilum & 0.496 \\
\hline Dinof. & Oxytoxum variabile & 0.479 \\
\hline Dinof. & Gyrodinium spp. (small, $<30 \mu \mathrm{m}$ ) & 0.479 \\
\hline Dinof. & Ceratium furca & 0.467 \\
\hline Cil. & Mesodinium rubrum & 0.466 \\
\hline Dinof. & Gymnodinium fusus & 0.445 \\
\hline Dinof. & Erythropsis agilis & 0.441 \\
\hline Dinof. & Dinoflagellate cysts & 0.439 \\
\hline Dinof. & Oxytoxum scolopax & 0.434 \\
\hline Cil. & Peritrichous ciliates (medium, $30-60 \mu \mathrm{m}$ ) & 0.423 \\
\hline Dinof. & Gonyaulax polygramma & 0.420 \\
\hline Dinof. & Gymnodinium spp (medium, $30-60 \mu \mathrm{m}$ ) & 0.416 \\
\hline Dinof. & Protoperidinium divergens & 0.414 \\
\hline Cil. & Peritrichous ciliates (small, $<30 \mu \mathrm{m}$ ) & 0.407 \\
\hline Diat. & Rhizosolenia delicatula & -0.199 \\
\hline Diat. & Schröderella delicatula & -0.213 \\
\hline Flag. & Cryptophyceae spp. & -0.236 \\
\hline Diat. & Centric diatom spp. (medium, $30-60 \mu \mathrm{m})$ & -0.242 \\
\hline Dinof. & Triadinium polyedricum & -0.262 \\
\hline Dinof. & Prorocentrum minimum & -0.302 \\
\hline
\end{tabular}

showed the negative correlations (Table $1 ; r^{2}=0.6$ between $\log$ abundance ciliates plus dinoflagellates $v s$. PC 1 scores). Large diatoms were responsible for the positive loads on PC 2 (Table $2 ; r^{2}=0.72$ between $\log$ abundance diatoms vs. PC 2 scores); several dinoflagellates, the chrysophyceae Dictyocha fibula and the tintinid ciliate Salpingacantha sp. were the species with the highest negative loads on this PC 2. PC 3 defined on the 
Table 2. Correlation coefficients of the species and taxas selected for Principal Component Analysis (PCA) with the second principal component. The PCA made with the species present in at least $10 \%$ of the samples showed the greatest separation in communities, while still retaining the species belonging to the coastal domain. Only those species with higher correlations $(>0.20)$ are given. The species were grouped in diatoms (Diat.); dinoflagellates (Dinof.); flagellates other than dinoflagellates (Flag.) and ciliates (Cil.).

\begin{tabular}{llr} 
Group & \multicolumn{1}{c}{ Taxon } & PC2 \\
Diat. & Proboscia alata & 0.810 \\
Diat. & Leptocylindrus danicus & 0.741 \\
Diat. & Lauderia borealis & 0.713 \\
Diat. & Rhizosolenia imbricata Schrubsolei & 0.708 \\
Diat. & Chaetoceros spp. & 0.681 \\
Diat. & Rhizosolenia Stolterfothii & 0.677 \\
Diat. & Pseudo-nitzschia cf. seriata & 0.668 \\
Diat. & Schröderella delicatula & 0.622 \\
Diat. & Rhizosolenia fragillissima & 0.586 \\
Diat. & Centric diatom spp. (small, $<30 \mu m)$ & 0.541 \\
Diat. & Rhizosolenia delicatula & 0.527 \\
Diat. & Stauroneis membranacea & 0.502 \\
Dinof. & Protoperidinium divergens & 0.486 \\
Cil. & Mesodinium pulex & 0.479 \\
Dinof. & Protoperidinium curvipes & 0.478 \\
Dinof. & Protoperidinium steinii & 0.468 \\
Diat. & Thalassionema nitzschioides & 0.431 \\
Diat. & Pseudo-nitzshia pseudodelicatissima-like & 0.400 \\
Dinof. & Gymnodinium nanum & -0.238 \\
Flag. & Dictyocha fibula & -0.240 \\
Dinof. & Oxytoxum scolopax & -0.252 \\
Dinof. & Gonyaulax polygramma & -0.253 \\
Dinof. & Gymnodinium fusus & -0.259 \\
Dinof. & Oxytoxum variabile & -0.273 \\
Cil. & Salpingacantha sp. & -0.392 \\
& &
\end{tabular}

positive side a dinoflagellate assemblage while the large dinoflagellate Ceratium horridum, the diatom Nitzschia longissima, the chrysophyceae Solenicola setigera, and ciliates were on the negative side (Table 3). At this point, it must be indicated that with the results of the PCA carried out with the species present in 20 and $30 \%$ of the samples, the diatom assemblage identified by PC 2 was replaced by PC 3 .

c. Poleward flow and continental "outwelling." Geopotential anomaly distributions at 0 , 50 , and 100 dbar referred to 300 dbar (Figs. 3a-3c) show a clear poleward flow in the CTZ off the Rías Baixas, with a core of salinity $>35.70$ psu (Figs. 3d-3f). At surface, salinities as high as 35.70 psu were observed up to section 3, off Cape Finisterre (Fig. 3d), while at $150 \mathrm{~m}$ depth, water saltier than $35.70 \mathrm{psu}$ was restricted to the southernmost stations, 13 and 14 (not shown). This high salinity core weakened, narrowed and shoaled as it was 
Table 3. Correlation coefficients of the species and taxas selected for Principal Component Analysis (PCA) with the third principal component. The PCA made with the species present in at least $10 \%$ of the samples showed the greatest separation in communities, while still retaining the species belonging to the coastal domain. Only those species with higher correlations $(>0.20)$ are given. The species were grouped in diatoms (Diat.); dinoflagellates (Dinof.); flagellates other than dinoflagellates (Flag.) and ciliates (Cil.).

\begin{tabular}{llr} 
Group & \multicolumn{1}{c}{ Taxon } & PC3 \\
Dinof. & Cachonina niei & 0.708 \\
Dinof. & Prorocentrum compressum & 0.674 \\
Dinof. & Triadinium polyedricum & 0.608 \\
Dinof. & Prorocentrum vaginula & 0.568 \\
Dinof. & Prorocentrum minimum & 0.524 \\
Dinof. & Mesoporus perforatusr & 0.480 \\
Flag. & Flagellates (small, $<30 \mu \mathrm{m})$ & 0.433 \\
Dinof. & Dinophysis pulchella & 0.372 \\
Dinof. & Dinophysis rotundata & 0.327 \\
Dinof. & Prorocentrum balticum & 0.325 \\
Dinof. & Gymnodinium spp. $(<30 \mu \mathrm{m})$ & 0.323 \\
Flag. & Cryptophyceae spp. & 0.314 \\
Cil. & Peritrichous ciliates $($ medium, $30-60 \mu \mathrm{m})$ & -0.215 \\
Cil. & Peritrichous ciliates $(\mathrm{small},<30 \mu \mathrm{m})$ & -0.219 \\
Dinof. & Ceratium horridum & -0.237 \\
Diat. & Nitzschia longissima & -0.263 \\
Flag. & Solenicola setigera & -0.267 \\
Cil. & Pritrichous ciliates $(1 \mathrm{arge},>30 \mu \mathrm{m})$ & -0.298
\end{tabular}

displaced northward. At transect 1 the core of the poleward flow was $120 \mathrm{~km}$ wide with salinity $>35.78 \mathrm{psu}\left(\gamma_{\theta} \geq 26.87\right)$ at $80 \mathrm{~m}$ depth, while at transect 3 it narrowed to $60 \mathrm{~km}$ and the core ( $S \geq 35.76 \mathrm{psu}, \gamma_{\theta} \geq 25.91$ ) was located at $40 \mathrm{~m}$ depth (Figs. $3 \mathrm{~d}-3 \mathrm{f}$ ). For the same dates, Haynes and Barton (1990) described the presence of this high salinity core (salinity $\sim 37.79 \mathrm{psu}$ ) at $100 \mathrm{~m}$ depth as far south as $40 \mathrm{~N}$, being a part of a poleward flow at an average speed of $0.27 \mathrm{~m} \cdot \mathrm{s}^{-1}$ throughout the upper $400 \mathrm{~m}$.

Nutrients were depleted at the surface, except off the River Miño, where silicate reached $7 \mu \mathrm{mol} \cdot \mathrm{kg}^{-1}$ (Fig. 4a). At $50 \mathrm{~m}$ depth, relatively high nutrient levels were found over the shelf while offshore low concentrations were observed except off the coast between Cape Finisterre and Cape Ortegal due to an upwelling center (Fig. 4b). In waters shallower than $100 \mathrm{~m}$ depth, low nutrient levels, $<6 \mu \mathrm{mol} \cdot \mathrm{kg}^{-1}$ of nitrate (not shown) and $2 \mu \mathrm{mol} \cdot \mathrm{kg}^{-1}$ of silicate, were associated with the core of the poleward flow, as must be expected for waters of subtropical origin. The distributions of "NO" conservative variable introduced by Broecker (1974; "NO" $=\mathrm{O}_{2}+9.3 \times \mathrm{NO}_{3}$ ) (Figs. 4d-4f), were coherent with the thermohaline structure, with lower values $\left(300 \mu \mathrm{mol} \cdot \mathrm{kg}^{-1}\right)$ associated with the core. Concentration of nitrite and ammonium was low. Along the main axis of the poleward flow, the highest nitrite levels $\left(0.1 \mu \mathrm{mol} \cdot \mathrm{kg}^{-1}\right)$, were associated with the maximum salinities, 

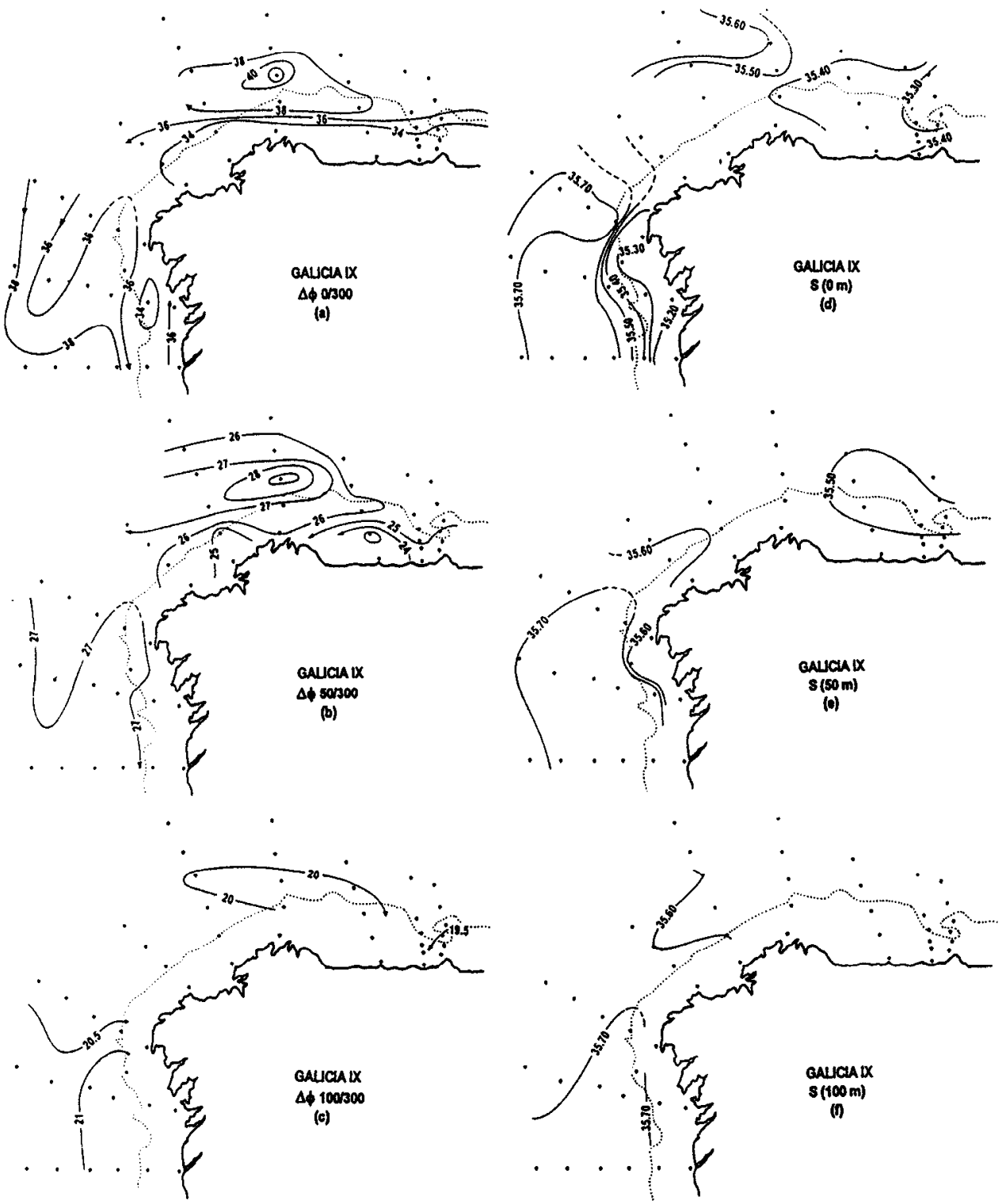

Figure 3. Dynamic topography charts referred to $300 \mathrm{dbar}$ (number in dynamics centimeters) at sea surface (a); $50 \mathrm{dbar}(\mathrm{b}) ; 100 \mathrm{dbar}(\mathrm{c})$; and horizontal distributions of salinity (psu) at sea surface (d); $50 \mathrm{dbar}(\mathrm{e})$ and $100 \mathrm{dbar}$ (f). Dashed lines, suggested isoline extension at the discontinuity in the sampling program (see Fig. 1). 


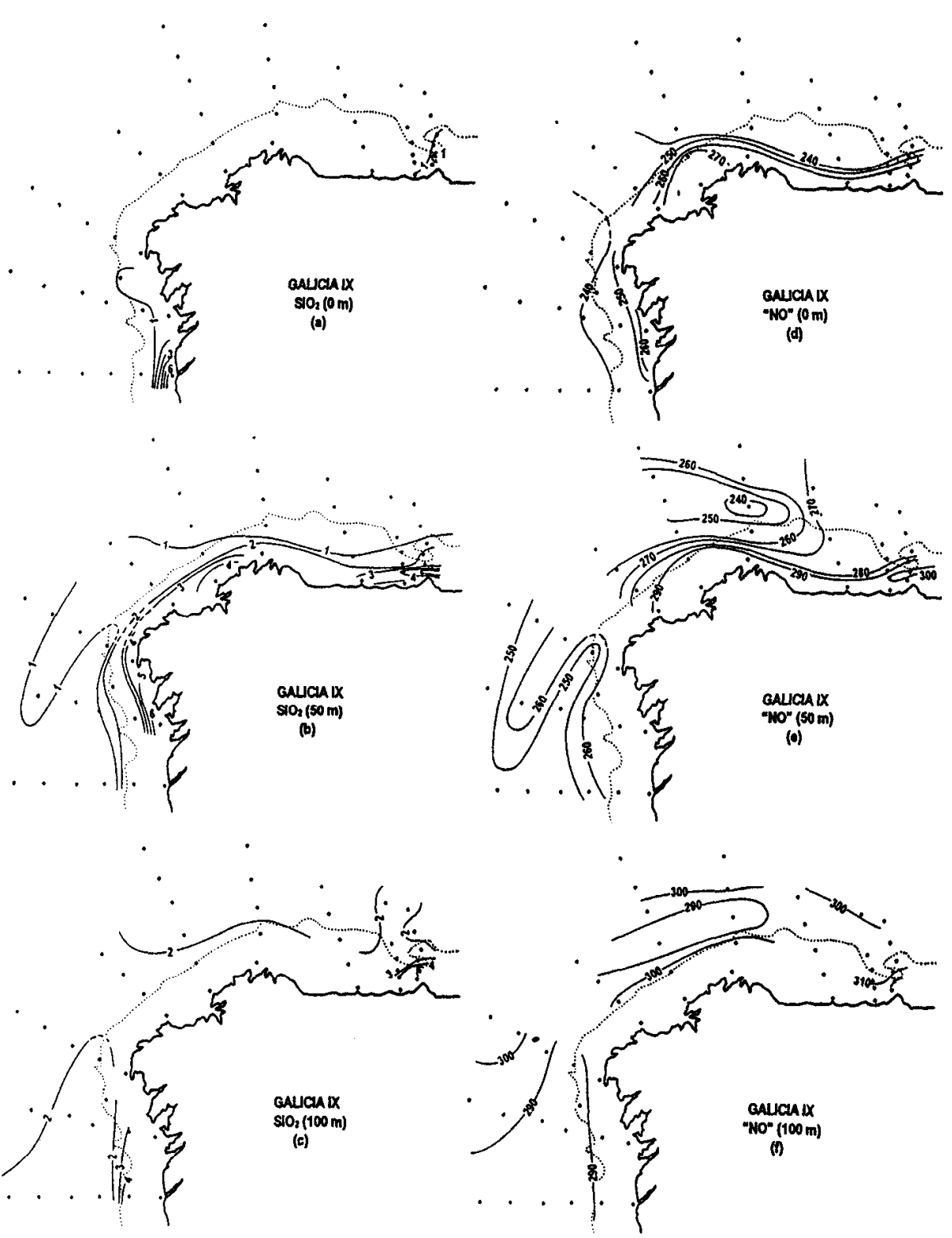

Figure 4. Horizontal distributions of silicate at sea surface (a); $50 \mathrm{dbar}$ (b); $100 \mathrm{dbar}$ (c); and horizontal distributions of "NO" at sea surface (d); $50 \mathrm{dbar}$ (e) and $100 \mathrm{dbar}$ (f). Units are $\mu \mathrm{mol} \cdot \mathrm{kg}^{-1}$. Dashed lines, suggested isoline extension at the discontinuity in the sampling program (see Fig. 1). 
while ammonium did not follow any pattern related to the core. Chl $a$ concentration was maximum at the nutricline, reaching $1.20 \mathrm{mg} \cdot \mathrm{m}^{-3}$ at station 24 .

The surface Chl $a$ distribution (Fig. 5a) showed the highest values confined over the shelf with two maxima located in the upwelling center north of Cape Finisterre and off the Rías Baixas, respectively. The maximum on the west coast was due to diatom and dinoflagellate populations (Figs. $5 \mathrm{c}$ and $5 \mathrm{e}$ ). In this area, small dinoflagellates dominated reaching values as high as $10 \times 10^{4}$ cells $\cdot l^{-1}$ (Gymnodinium simplex, G. nanum, Gymnodinium spp., Cachonina niei, Scrippsiella trochoidea), while diatoms were between $10-50 \times 10^{3}$ cells $\cdot l^{-1}$ (Leptocylindrus danicus, Pseudo-nitzschia cf. seriata, Pseudonitzschia pseudodelicatissima-like, Chaetoceros spp.). However, at $50 \mathrm{~m}$ depth the maximum Chl $a$ values were found in the oceanic stations off the Rías Baixas (Fig. 5b). This maximum was associated with the high salinity core of the poleward flow (see Figs. $3 \mathrm{~b}$ and $3 e$ ) and was exclusively due to small dinoflagellates (Figs. $5 \mathrm{~d}$ and $5 \mathrm{f}$ ) with high values of $39 \times 10^{3}$ cells $\cdot l^{-1}$.

The two microplankton assemblages defined by PC 1 were spatially segregated, with negative scores in the Northern area and positive scores off the Rías Baixas (Figs. 6a-6b). The large-diatoms assemblage, identified by PC 2 , strongly reflected coastal upwelling and outwelling from the Rías Baixas (Figs. 6c-6d). The PC 3 showed more complex horizontal distributions, being the positive scores related with the oceanic influence (Figs. 6e-6f).

The poleward flow domain was also distinguished by PC 1 and PC 3 horizontal distributions while the poleward flow signal on PC 2 distributions was only slightly observed at $50 \mathrm{~m}$ depth. At the surface the poleward flow seemed to interrupt the continuous cross-shore gradient from the Rías Baixas in the microplankton assemblages defined by PC 1 and PC 3 . At $50 \mathrm{~m}$ depth the maximum positive values of PC 1 and PC 3 were associated with the high salty core. Also, the large diatoms identified by PC 2 were absent at $50 \mathrm{~m}$ depth in the CTZ.

The poleward flow in the CTZ determined the chemical and biological fields over the adjacent shelf. The poleward flow prevented the "outwelling" from the Rías Baixas, abutting it at the inner stations. The vertical distribution of salinity along transect 1 (Fig. 7b) shows how the poleward flow interrupted the tongue of estuarine water, with extreme values of $33.1 \mathrm{psu}$. An associated uplift of the nutricline occurred, rising from $60 \mathrm{~m}$ depth at the main axis of the poleward flow (stns. 13 and 14) to $15 \mathrm{~m}$ depth over the shelf (sta. 12; Fig. $7 \mathrm{c}$ and d). The Chl $a$ distribution (Fig. 8a) followed that of nitrate, with maximum values at the nutricline. $\mathrm{Chl} a$ concentrations up to $3 \mathrm{mg} \cdot \mathrm{m}^{-3}$, were found near the surface on the shelf, whereas it deepened oceanward and formed a marked subsurface maximum of $1 \mathrm{mg} \cdot \mathrm{m}^{-3}$ in the poleward flow domain. Significant concentrations of nitrite and ammonium (Fig. 7e and 7f) were only found on the shelf. Ammonium concentration $>7 \mu \mathrm{mol} \cdot \mathrm{kg}^{-1}$, followed by subsequent maxima of nitrite and nitrate downward were found below the Chl $a$ patch.

The vertical distribution of total cell numbers at transect 1 presented two maxima, one over the shelf and the other at the oceanic extreme (Fig. 8b). The poleward flow was 

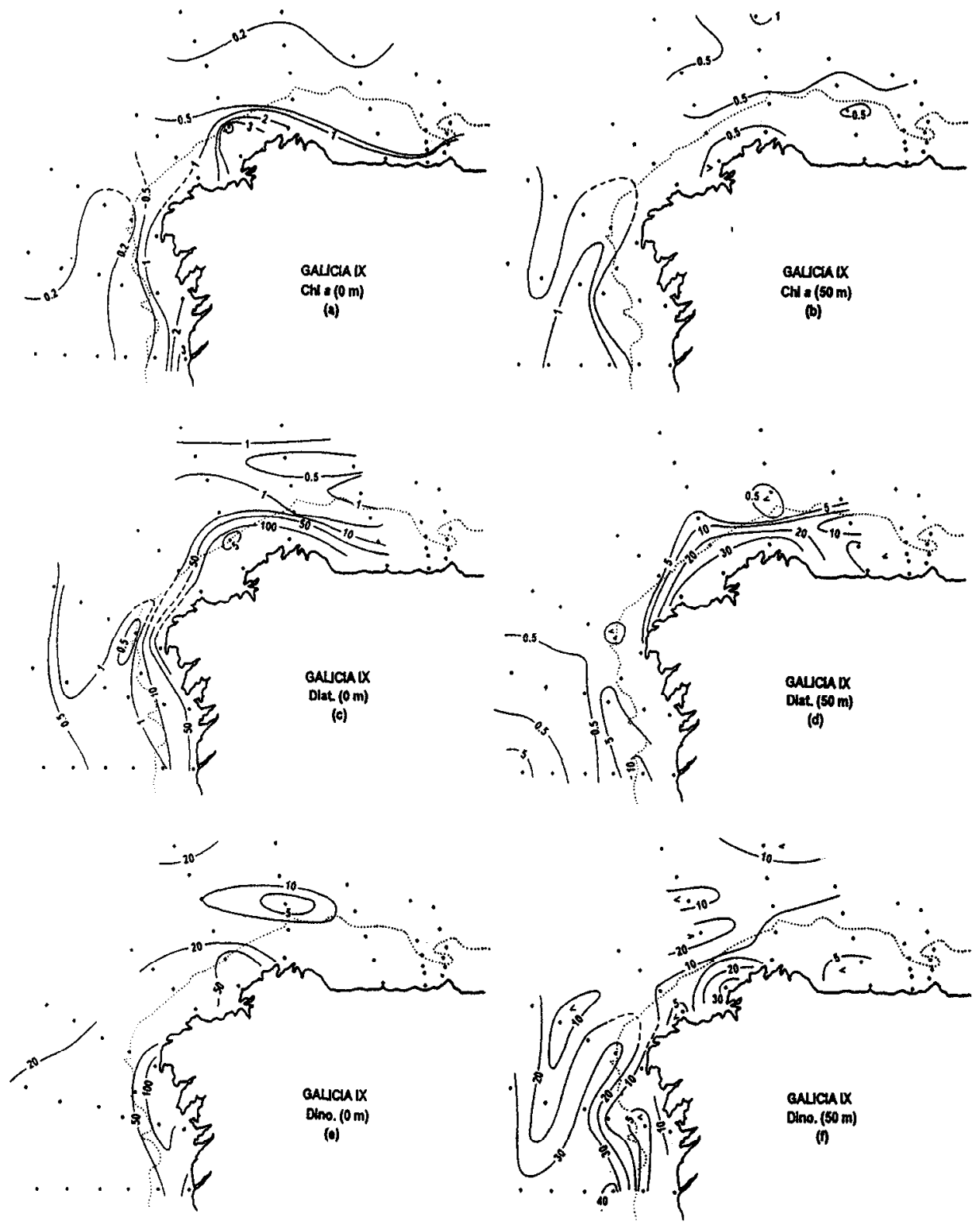

Figure 5. Horizontal distributions of Chl $a$ at sea surface (a) and $50 \mathrm{dbar}$ (b) diatoms concentration at sea surface (c) and $50 \mathrm{dbar}(\mathrm{d})$ and of dinoflagellates concentration at sea surface (e) and $50 \mathrm{dbar}$ (f) Chl $a$ in $\mathrm{mg} \cdot \mathrm{m}^{-3}$ and cells concentrations in cells $\cdot l^{-1}\left(\times 10^{3}\right)$. Dashed lines, suggested isoline extension at the discontinuity in the sampling program (see Fig. 1). 

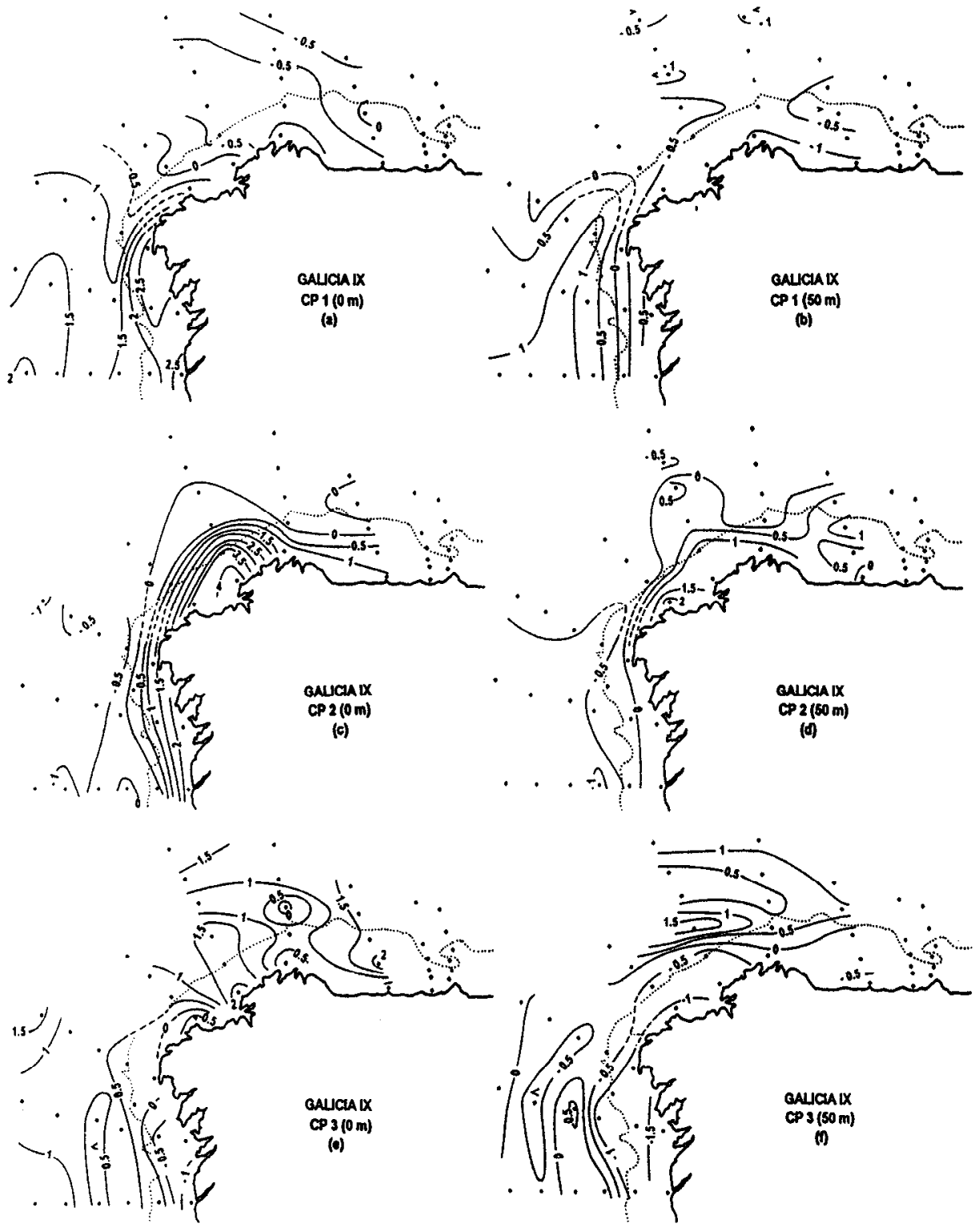

Figure 6. Horizontal distributions of scores of the principal component PC 1 of the phytoplankton at sea surface (a) and $50 \mathrm{dbar}$ (b) of the PC 2 at sea surface (c) and $50 \mathrm{dbar}$ (d) and of the PC 3 at sea surface (e) and $50 \mathrm{dbar}$ (f). Dashed lines, suggested isoline extension at the discontinuity in the sampling program (see Fig. 1). 


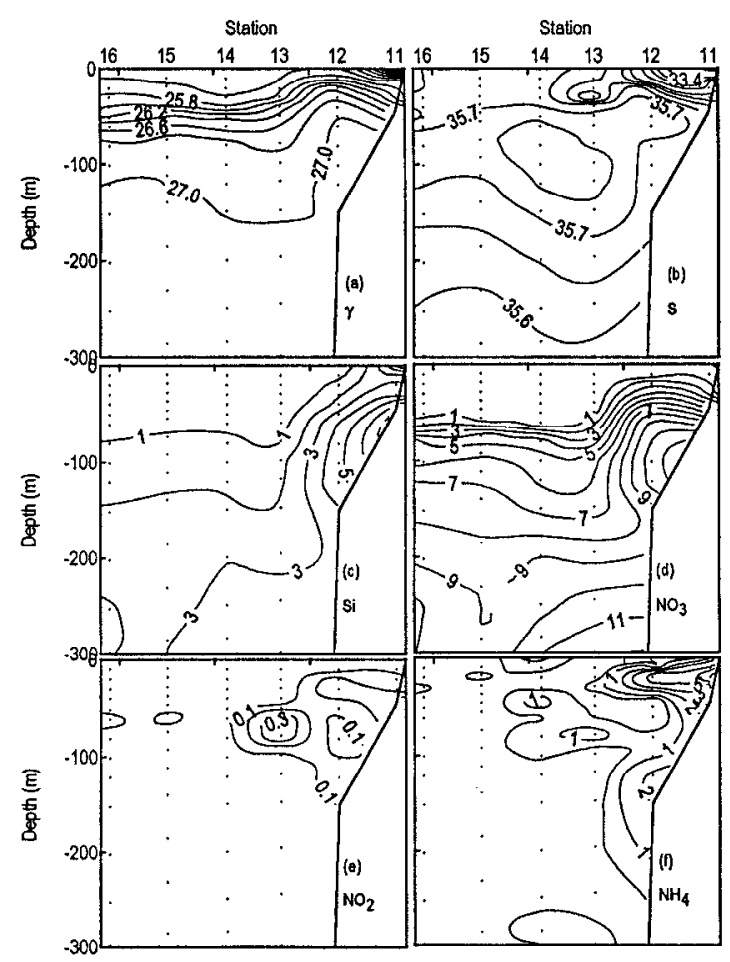

Figure 7. Vertical distributions of density excess (a); salinity (b); silicate (c); nitrate (d); nitrite (e); and ammonium (f) for cross-shelf transect 1 off River Miño. Salinity in psu and nutrients in $\mu \mathrm{mol} \cdot \mathrm{kg}^{-1}$.

characterized by low cell numbers with no diatoms and dominance of dinoflagellates (Figs. $8 \mathrm{c}$ and $8 \mathrm{~d}$ ). The oceanic maximum was composed by small flagellates and ciliates which were also present on the coastal waters (Figs. 8e and 8f). Over the shelf, diatoms and dinoflagellates significantly contributed to the total population. Nevertheless, several large dinoflagellates species like Gymnodinium catenatum, Ceratium furca, C. fusus, and Protoperidinium divergens were present over the shelf. Meanwhile, they were not found in the subsurface offshore maximum, where small naked dinoflagellates prevailed.

d. Anticyclonic eddy and upwelling front. North of Cape Finisterre, the most striking feature was an approximately elliptical anticyclonic eddy off Cape Ortegal. It was about $147 \mathrm{~km}$ long, $20 \mathrm{~km}$ wide at the surface and $100 \mathrm{~m}$ deep, as can be observed in the horizontal distribution of geopotential anomaly (Figs. 3a-3c). Surface salinity (Fig. 3d) hardly traced the eddy. From Cape Peñas to Cape Ortegal, westward advection of surface water with salinity $<35.40$ psu was observed. At the outermost stations of transects 4 and 5 , eastward advance of salty water (salinity $>35.60 \mathrm{psu}$ ) occurred, probably interrupted by the less saline surface waters from the Cantabrian Sea. At 50 and $100 \mathrm{~m}$ depth, salinity 


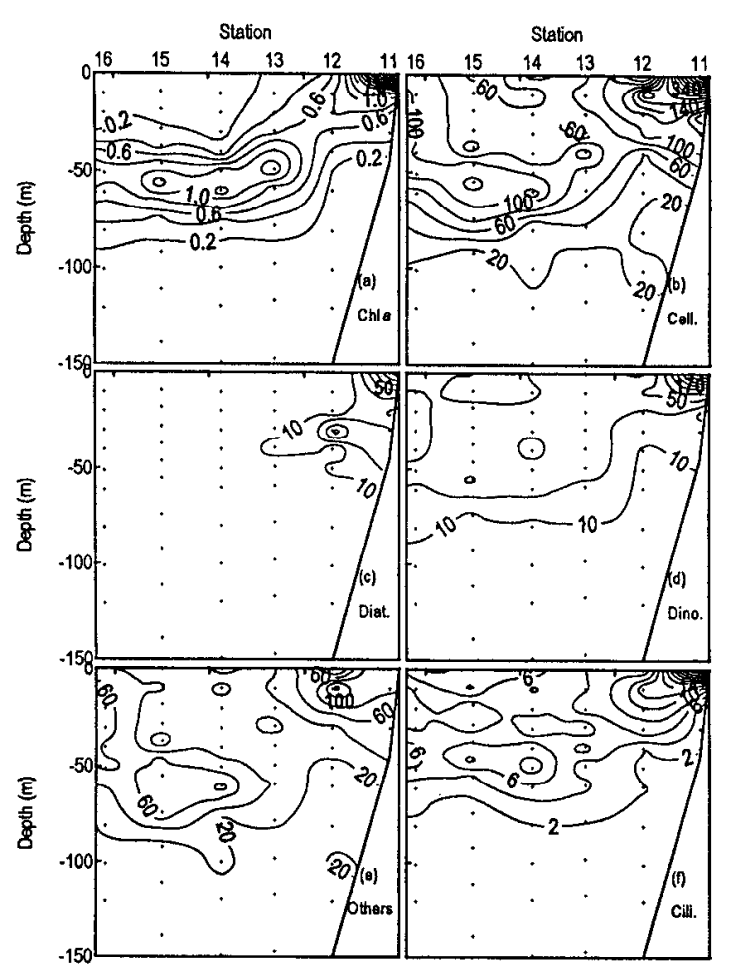

Figure 8. Vertical distributions of Chl $a$ (a); cell abundance (b); diatoms (c); dinoflagellates (d); others (e) and ciliates concentration ( $f$ ) for cross-shelf transect 1 off River Miño. Chl $a$ in $\mathrm{mg} \cdot \mathrm{m}^{-3}$ and cells concentrations in cells $\cdot l^{-1}\left(\times 10^{3}\right)$.

higher than 35.55 psu (Figs. 3e and 3f), was associated to the eddy. At $150 \mathrm{~m}$ (not shown) the signal disappeared.

Sinking of the pycnocline by the anticyclonic rotation of the eddy extended to $120 \mathrm{~m}$ depth, as observed in the vertical distribution of $\gamma_{\theta}$ (Fig. 9a). The center of the eddy, with salinity $35.59 \mathrm{psu}$, was between 30 and $60 \mathrm{~m}$ depth at station 63 (Fig. 9b). Its thermohaline properties corresponded to surface water, with salinity ranging from 35.57 to $35.59 \mathrm{psu}$ and temperature $>12^{\circ} \mathrm{C}$.

$\theta-S$ diagrams for water samples in the upper $100 \mathrm{~m}$, corresponding to stations in the eddy center (station 63), around the eddy (stations 43, 61,65 and 74), and in the main axis of the poleward flow (station 14) are depicted in Figure 10a with a reference line for the Eastern North Atlantic Central (ENACW) given by Fiuza (1984). Salinity at the eddy center was $0.02 \mathrm{psu}$ lower than in the poleward flow but higher than in the surrounding stations, pointing a southern origin for water in the eddy. The strongest salinity gradient, $0.002 \mathrm{psu} \cdot \mathrm{km}^{-1}$, was found between the eddy center and station 74, where Cantabrian Sea surface water prevailed.

From a chemical point of view, relatively low nutrients concentrations, $1.5 \mu \mathrm{mol} \cdot \mathrm{kg}^{-1}$ 


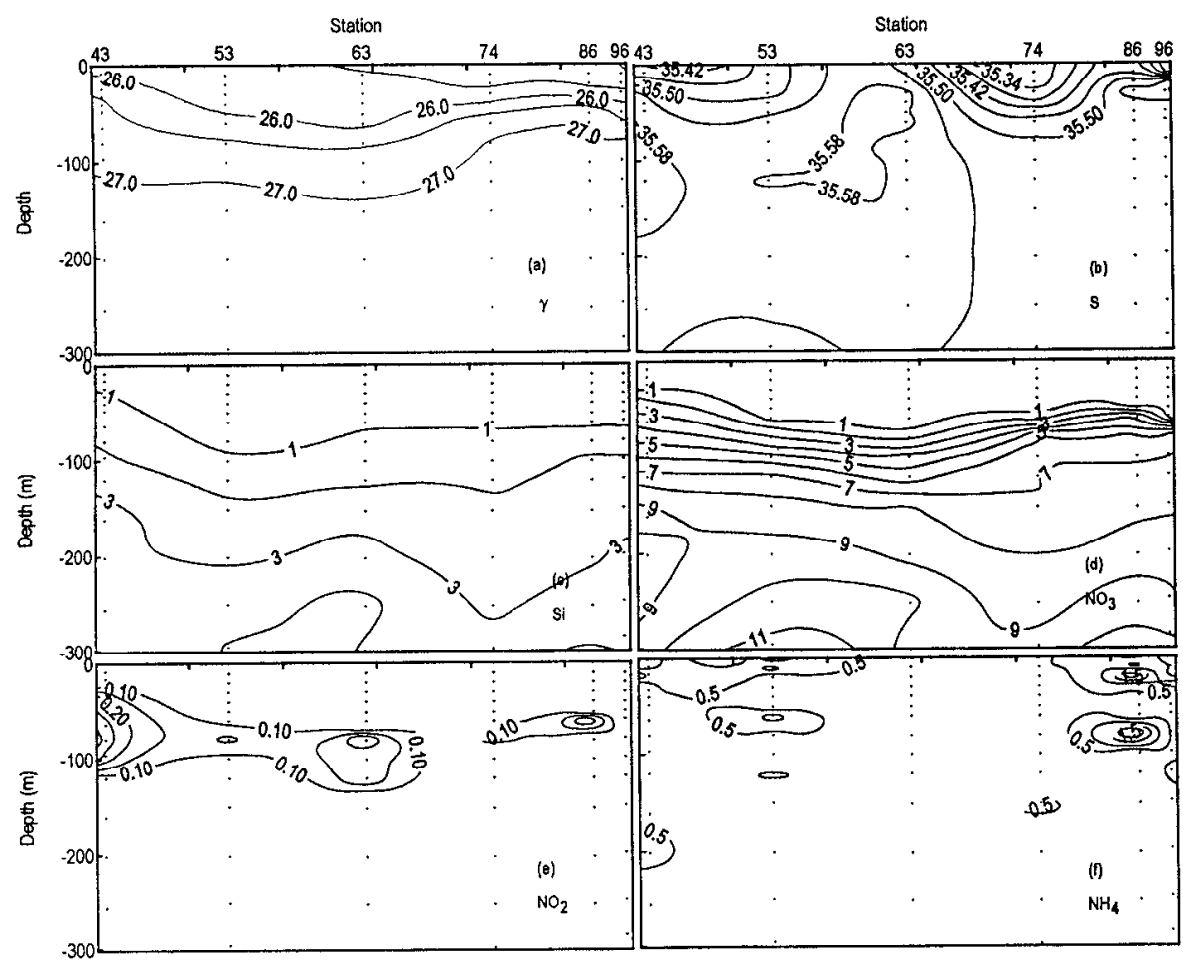

Figure 9. Vertical distributions of density excess (a); salinity (b); silicate (c); nitrate (d); nitrite (e) and ammonium (f) for a section across the eddy. Salinity in psu and nutrients in $\mu \mathrm{mol} \cdot \mathrm{kg}^{-1}$.

of silicate (Fig. 4c) and $5.0 \mu \mathrm{mol} \cdot \mathrm{kg}^{-1}$ of nitrate (not shown) and low levels of "NO," $\sim 300 \mu \mathrm{mol} \cdot \mathrm{kg}^{-1}$ (Fig. $4 \mathrm{f}$ ), at $100 \mathrm{~m}$ depth were observed associated to the eddy. At 0 and $50 \mathrm{~m}$ depth, signal of the eddy in the nutrient field (Figs. $4 \mathrm{a}$ and $4 \mathrm{~b}$ ) was not evident due to depletion at the offshore stations, except off Punta Roncudo where an intense upwelling center was found. However, "NO" at $50 \mathrm{~m}$ depth (Fig. 4e) revealed low values $\left(<250 \mu \mathrm{mol} \cdot \mathrm{kg}^{-1}\right)$ associated with the eddy, similar to those found in the poleward flow domain. At $150 \mathrm{~m}$ depth there was no chemical signal of the eddy. The vertical distribution of nitrate (Fig. 9d) shows the deepening of the nutricline at the eddy center, at about $70 \mathrm{~m}$ depth in station 63. At depths greater than $120 \mathrm{~m}$, a different pattern was observed. There was a frontal zone between stations 63 and 74 formed by Bay of Biscay Central Water (BBCW) advected westward and Eastern North Allantic Central Water (ENACW) from the Southwest. Such front was previously described by Fraga et al. (1982) off Cape Finisterre.

Plots of $\mathrm{SiO}_{2}$ vs $\theta$ and "NO" vs $\theta$ for the same stations as in Figure 10a are shown in Figures $10 \mathrm{~b}$ and $10 \mathrm{c}$. For temperatures $>16^{\circ} \mathrm{C}$, nutrients were almost depleted. For colder waters, $\mathrm{SiO}_{2}$ and "NO" concentrations were very similar to those found in the poleward flow (station 14). Stations 65 and 74, located in the domain of the low-salinity Cantabrian Sea waters, were characterized by lower nutrient levels for the same temperatures. 


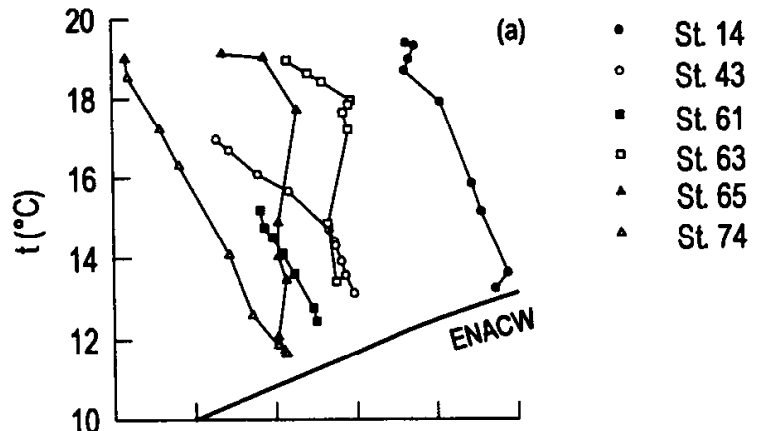

$\begin{array}{llllll}35.3 & 35.4 & 35.5 & 35.6 & 35.7 & 35.8\end{array}$
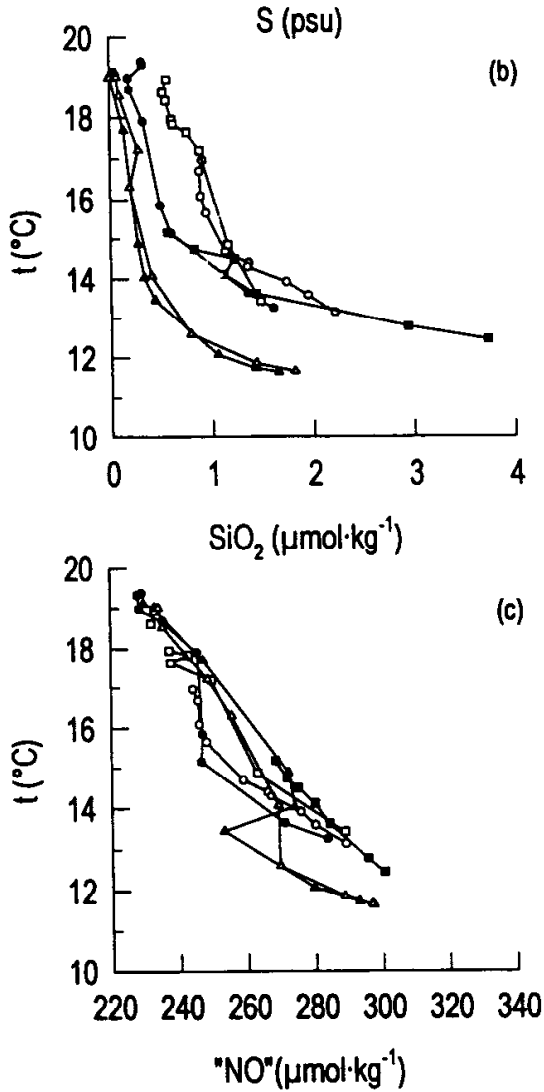

Figure 10. Plots of potential temperature vs. salinity with a reference line for ENACW (a), temperature $v s$. silicate (b) and temperature $v s$ "NO" (c) for water samples in the upper $100 \mathrm{~m}$ of stations in the eddy centre (sta. 63), around it (sta. 43, 61, 65 and 74) and in the poleward domain (sta. 14). 


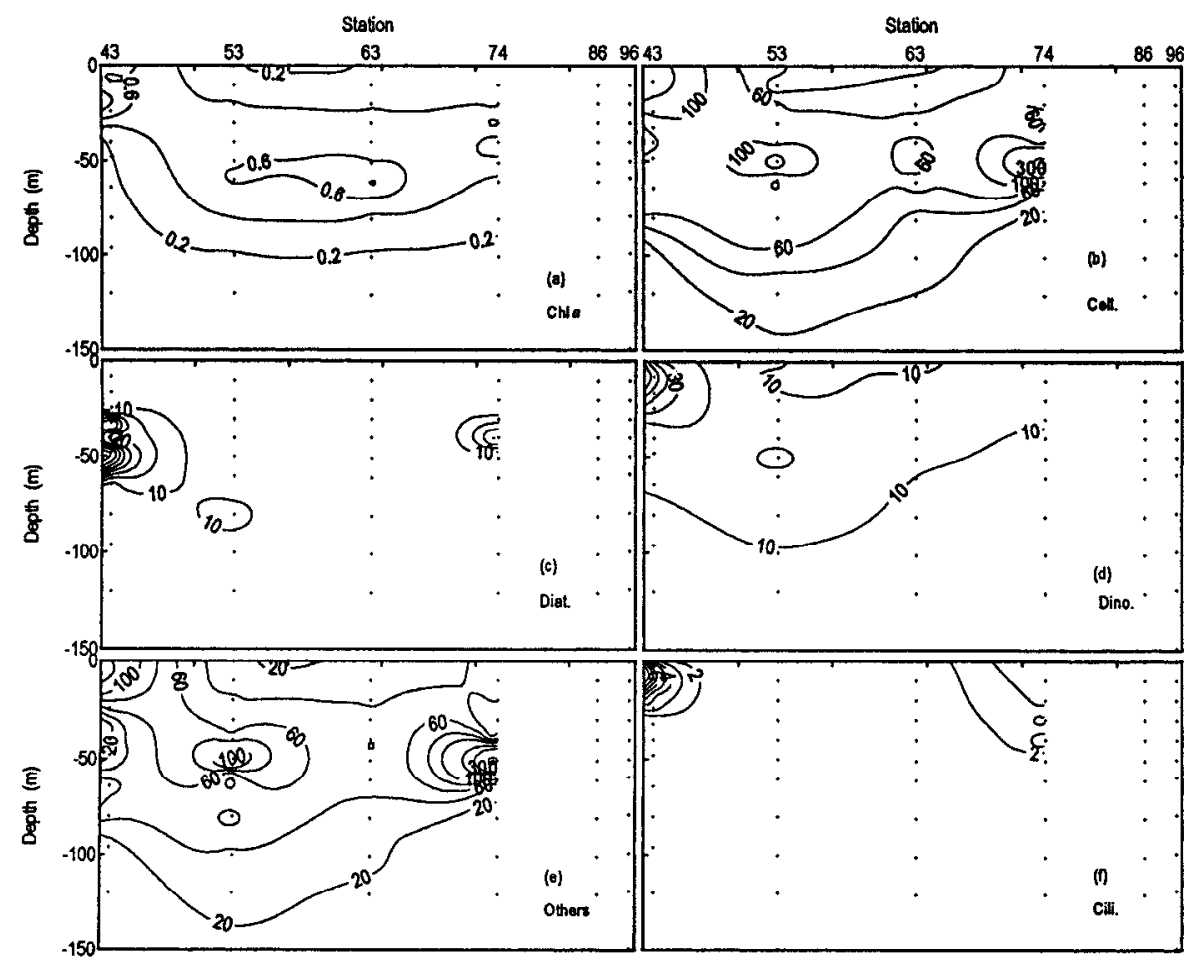

Figure 11. Vertical distributions of Chl $a$ (a); cell abundance (b); diatoms (c); dinofiagellates (d); others (e) and ciliates concentration (f) for a section across the eddy. Chl $a$ in $\mathrm{mg} \cdot \mathrm{m}^{-3}$ and cells concentrations in cells $\cdot l^{-1}\left(\times 10^{3}\right)$.

Therefore, the chemical field followed the thermohaline structure. These thermohaline and chemical properties do not suggest a local origin but a southern origin for the water masses of the eddy, due to their resemblance with the poleward flow off the Rías Baixas.

The Chl $a$ distribution at the surface did not reveal the presence of the eddy, while the horizontal distributions of diatoms and dinoflagellates showed minima at the eddy domain (Figs. 5a, 5c and 5e). The diatoms distribution at $50 \mathrm{~m}$ depth also presents a minima at the eddy domain, while the dinoflagellates distribution did not show any distinctive structure in the eddy region (Figs. 5d and 5f). In the same way, the horizontal distributions of PC 1 and PC 2 at 0 and $50 \mathrm{~m}$ depth show no signal of the eddy (Figs. 6a-6d). Nevertheless, the imprint of the eddy structure was reflected in the horizontal distribution of PC 3 with a stronger signal at surface (Fig. 6e). At $50 \mathrm{~m}$, the eddy was slightly masked by the maximum positive values found at station 53 probably due to local downward transport of surface populations (Fig. 6f).

The Chl $a$ structure (Fig. 11a) in the eddy was also very similar to that previously found in the poleward flow off the Rías Baixas, with the maximum at the nutricline and the nitrite maximum immediately below (Fig. 9e). Therefore, considering the same southern origin 


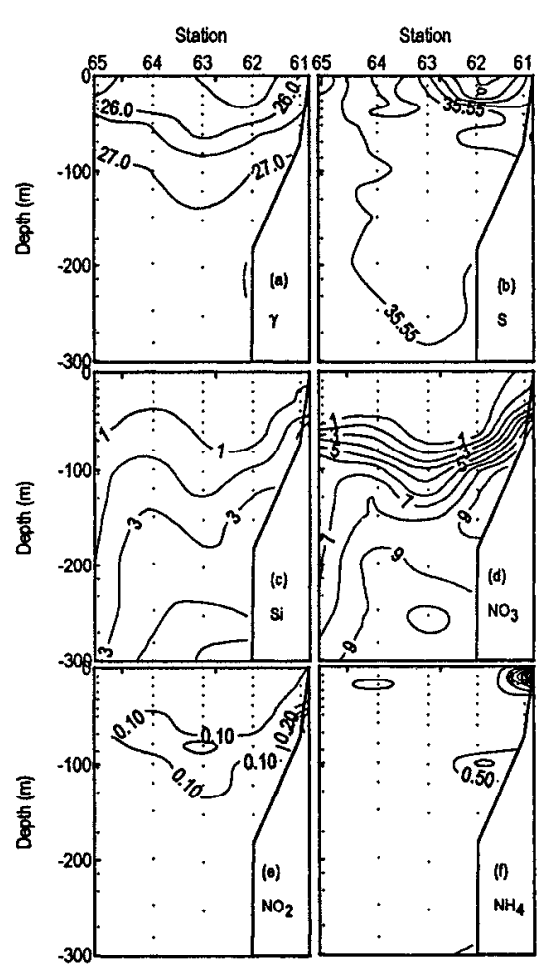

Figure 12. Vertical distributions of density excess (a); salinity (b); silicate (c); nitrate (d); nitrite (e); and ammonium (f) for cross-shelf transect 6 off Cape Ortegal. Salinity in psu and nutrients in $\mu \mathrm{mol} \cdot \mathrm{kg}^{-1}$.

for the water masses of the eddy and the poleward flow, the lower Chl $a$ and higher nitrite concentration compared to the poleward flow suggest a relatively ageing of the eddy regarding the poleward flow. In this sense, we can consider the eddy an isolated parcel of water of subtropical origin. The subsequent evolution of the eddy will depend on its degree of isolation. The presence of frontal zoncs supports the possibility of entrainment of water from the surroundings (Simpson, 1984). In the transect off Cape Ortegal (Fig. 12) an upwelling front between stations 61 and 62 from surface to $60 \mathrm{~m}$ depth, was observed. Farther north, there was a salinity front between stations 65 and 64, not reflected in nutrient distributions. The distribution of $\mathrm{Chl} a$ (Fig. 13a) for this transect showed a homogeneous patch at station 61 while a subsurface $\mathrm{Chl} a$ maximum was observed offshore. The $\mathrm{Chl} a$ minimum at station 62 , pointed out a discontinuity between coastal upwelling and eddy, also reflected in the diatom and total cells distributions for this transect (Figs. 13c and 13b). Therefore, limited entrainment between both domains can be assumed. However, entrainment from the northward edge to the eddy center was observed at the nutricline $(50 \mathrm{~m}$ depth) according to the Chl $a$ and the other microplankton groups (Figs. 13d-13e). The salinity distribution along a section across the eddy (Fig. $9 \mathrm{~b}$ ) showed the presence of a 


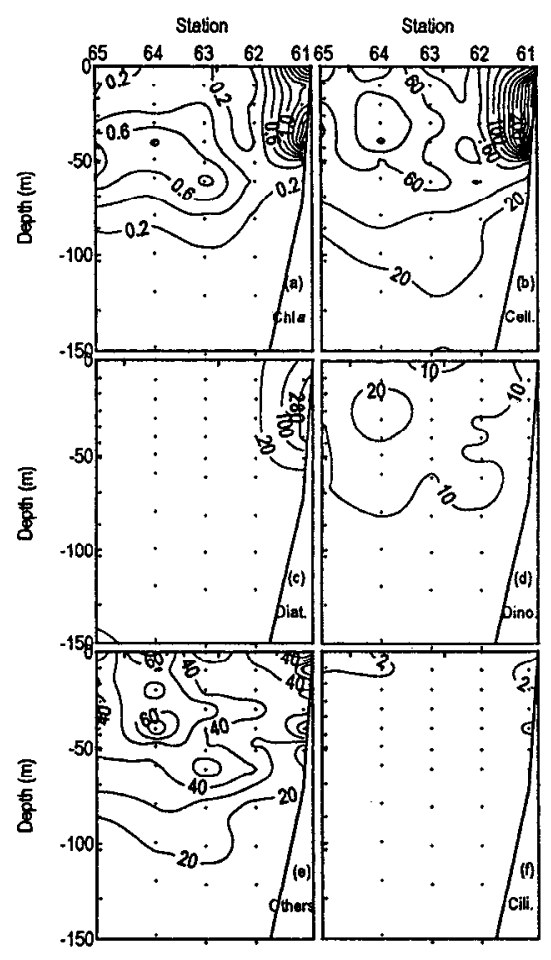

Figure 13. Vertical distributions of Chl $a$ (a); cell abundance (b); diatoms (c); dinoflagellates (d); others (e) and ciliates concentration (f) for cross-shelf transect 6 off Cape Ortegal. Chl $a$ in $\mathrm{mg} \cdot \mathrm{m}^{-3}$ and cells concentrations in cells $\cdot l^{-1}\left(\times 10^{3}\right)$.

salinity front located between stations 63 and 74. This salinity front was more intense throughout the upper 75 meters. At the western boundary of the eddy, low salinity values corresponded to upwelled water. Taking into account the Chl $a$ distribution of the upper $150 \mathrm{~m}$ (Fig. 11a), the eddy is characterized by an enclosed subsurface patch with no continuity with the surroundings, suggesting the lack of entrainment in the west-east direction. Total cell numbers, diatoms, and small flagellate distribution support this statement (Figs. 11b-11e). Solenicola setigera, the main responsible species of the cell maximum at station 74 , was completely absent at the other stations. Small flagellates, Cachonina niei, small Gymnodinium spp. and Prorocentrum minimum were the more abundant species at surface waters of station 43 .

From Punta Roncudo to Cape Peñas, there was a strong upwelling front with a temperature gradient of $0.2^{\circ} \mathrm{C} \cdot \mathrm{km}^{-1}$. The coldest temperatures were reached off Cape Prior $\left(<15^{\circ} \mathrm{C}\right.$, not shown). The 27.0 isopycnal rose from $120 \mathrm{~m}$ depth at station 63 to $60 \mathrm{~m}$ depth at station 61 (Fig. 12a) in contrast to the transects east of Cape Ortegal, where the 27.0 isopycnal rose only $40 \mathrm{~m}$ in $32 \mathrm{~km}$ (Fig. 14a). Nutrient distributions west of Cape Ortegal were also very different from those east of the cape. At stations 51 and 61 nitrate 


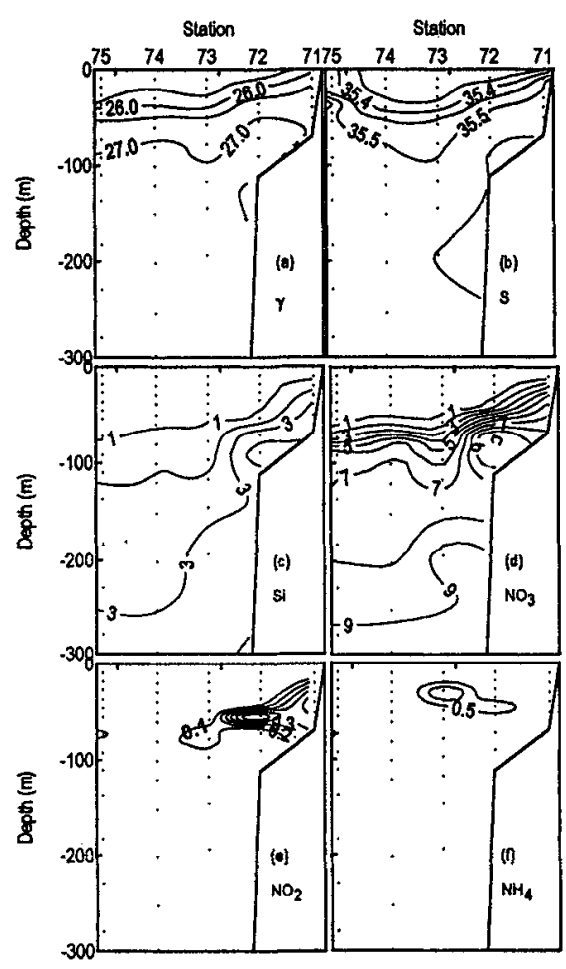

Figure 14. Vertical distributions of density excess (a); salinity (b); silicate (c); nitrate (d); nitrite (e); ammonium (f) for cross-shelf transect 7 off Cape Vidio. Salinity in psu and nutrients in $\mu \mathrm{mol} \cdot \mathrm{kg}^{-1}$.

concentrations $>1 \mu \mathrm{mol} \cdot \mathrm{kg}^{-1}$ (Fig. 12d), were reached at the surface, while at shelf stations east of Cape Ortegal, nitrate was completely depleted at the surface (Fig. 14d). Silicate distributions (Figs. 12c and 14c) showed an opposite trend, with complete consumption at stations 51 and 61 . Two patterns in the upwelling region can also be discerned from the $\mathrm{Chl} a$ distributions (Fig. 13a and 15a). The highest biomass was found at the shelf stations west of Cape Ortegal. At station 51 depth-integrated Chl $a$ was $102 \mathrm{mg} \cdot \mathrm{m}^{-2}$, while lower levels of 60,40 and $47 \mathrm{mg} \cdot \mathrm{m}^{-2}$ were found at stations 71,81 and 91, respectively. West of Cape Ortegal, the highest Chl $a$ levels were found over the shelf, almost exclusively attributed to diatoms (Fig. 13). The absence of these populations offshore pointed to no export from the shelf. There was a subsurface $\mathrm{Chl} a$ maximum at offshore stations composed of small flagellates and small dinoflagellates (Cachonina niei, Gymnodinium spp. Prorocentrum minimum). East of Cape Ortegal, the situation was different (Fig. 15). The maximum Chl $a$ levels were found again at the shelf and consisted mainly of diatoms (Chaetoceros socialis, Leptocylindrus minimus, Pseudo-nitzschia spp. Rhizosolenia delicatula, Schröderella delicatula), dinoflagellates and small flagellates. At 
oceanic stations the Chl $a$ levels were very low, where the most important feature was the presence of a subsurface patch of nophototrophic specie Solenicola setigera at station $\mathbf{7 4 .}$

\section{Discussion}

Poleward flows are typical features of upwelling systems in eastern boundaries (Lynn and Simpson, 1987; Mittelstaedt, 1991; Huyer, 1980). Thickness, strength and position of this flow relative to the continental slope vary depending on the upwelling region. There is also seasonal variability attributed to changes of midocean atmospheric high pressure systems (Wooster et al., 1976; Brockmann et al., 1980; Mittelstaedt, 1983; 1991; Lynn and Simpson, 1987).

In the NW Iberian Upwelling System, there are few observations of an annual cycle of currents at mid-depths $(100-400 \mathrm{~m})$, because most of the research in the area has been focused on studying the northward spreading of the Mediterranean overflow. All direct current measurements conducted in the area from 200 to $1500 \mathrm{~m}$ indicate mean flow to the north (Meincke et al., 1975; Swallow et al., 1977; Ambar, 1984; 1985; Kautsky et al., 1977). According to Fiúza (1982), this permanent poleward flow constitutes the usual compensation undercurrent of an upwelling system. However, the southward advance of Eastern North Atlantic Central Water (ENACW), formed north of Cape Finisterre (43N) (ENACW of subpolar origin), along the continental slope of the Iberian Peninsula has been described by several authors (Fraga et al., 1982; Ríos et al., 1992; Pérez et al., 1993). Above this layer, subtropical ENACW, formed south of 43N (Ríos et al., 1992) displaces northward. Salinity of subtropical ENACW off Galicia increases throughout the year, being maximum in December, concomitant with a southwestward origin of the waters mass source (Ríos et al., 1992; Alvarez-Salgado et al., 1993). In this sense, we only consider the undercurrent of the Iberian upwelling system above $100 \mathrm{~m}$ depth, basically dominated by subtropical ENACW.

The hydrographic and chemical fields during the GALICIA-IX supported the idea that the poleward flow constituted the compensation undercurrent, which surfaces during the winter. The thermohaline and chemical characteristics of the salty core of the poleward flow correspond to ENACW of subtropical origin, and surface water can be considered as ENACW modified by heating, nutrient consumption by phytoplankton and subsequent biological processes on the food web. The poleward flow was characterized by dinoflagellates and small flagellates, as the spring salty intrusion described by Fernández et al. (1991) off Cape Peñas. In the case here, lower cell numbers were observed as it corresponds to an autumn intrusion of stratified waters. Absence of diatoms indicated its oceanic origin (Malone et al., 1983).

Currents obtained from a mooring off Cape Ortegal (Pingree and Le Cann, 1990), showed strong seasonality with maximum poleward flow from October to January at $210 \mathrm{~m}$ depth. At $481 \mathrm{~m}$ depth opposite mean currents were observed, but only a weak eastward current from July to October. Consequently, there is practically no compensation undercurrent during the upwelling season in the northern coast. The situation is very 
similar to that found in the California Current system. During the upwelling season, the poleward California Undercurrent, CU (Sverdrup and Fleming, 1941) became faster and shallower to the south of Cape Mendocino whereas immediately north of the cape it became weaker (Largier et al., 1993; Bray and Greengrove, 1993). From August to November the poleward flow gets stronger and shoals, encompassing from the surface down to $400 \mathrm{~m}$.

The most striking feature of the poleward flow was the role in preventing the cross-shelf exchange of continental water and the microplankton population "outwelled" from the Rías Baixas. Blanton et al. (1987) previously discussed a similar situation based on the hydrographic field. Tilstone et al. (1994) reported a situation in which "outwelling" was blocked and the coastal populations were reintroduced into the rías. The cross-shelf nutrient distributions (Fig. 7), showed a clear vertical segregation pattern of the three inorganic nitrogen forms on the shelf. An intense ammonium maximum was observed just below the Chl $a$ maximum, similar to that found by Minas et al. (1982) in NW Africa. Nitrite was maximum $\left(>0.2 \mu \mathrm{mol} \cdot \mathrm{kg}^{-1}\right)$ at an intermediate depth, and the highest nitrate values were found at the bottom. This shallow ammonium maximum must be related to incipient oxidation of sinking particulates. The second maximum of ammonium found in the bottom layer over the shelf was probably due to diffusion from the sediments and rapid nitrification, which leads to the bottom nitrate maximum. This chemical situation reflected the biological field in which waters outwelled from the Rías Baixas were characterized by large-sized species, easily-sinking diatoms being an important component. Therefore, confinement of the shelf regime by the poleward flow favored particulate organic matter sedimentation (Monteiro et al., 1983) and the subsequent rapid oxidation over the shelf (Alvarez-Salgado et al., 1997).

Thermohaline and chemical properties of the eddy suggest a southern origin related to the poleward flowing high salinity water. In this sense, its origin is the same as the swoddies described by Pingree and Le Cann $(1990 ; 1992 a, b)$, though its structure and mechanism of formation seem to be different. Swoddies are characterized by being vertically homogeneous, and were composed of subtropical ENACW, in contrast to the surface structure that we found. Pingree and Le Cann (1992b) described the thermohaline structure of a swoddy in July 1990 formed off Cape Ferret the previous winter. Although its presence was felt to depths of $1500 \mathrm{~m}$, it was characterized by a mixed layer with $12.95^{\circ} \mathrm{C}$ and 35.74 psu from 65 to $260 \mathrm{dbar}$. We hypothesize that the mesoscale eddy surveyed during GALICIA-IX cruise was also formed from the slope current. The eastward advance of this flow along the Cantabrian continental slope was blocked by surface waters from the Cantabrian Sea. At the same time the continuity of the poleward flow was interrupted by the upwelling center off Finisterre and this parcel of water, with a southern origin, formed the mesoscale eddy. This process was probably topographically enhanced by Cape Ortegal. This southern origin is also supported by the phytoplankton distributions. The eddy was characterized by a minimum of diatom numbers as was the poleward flow, while the upwelling and Cantabrian waters presented high levels of this phytoplankton group. On 
the other hand, the horizontal distribution of PC 3 scores (Fig. 6e-6f) showed how the coastal-ocean gradient was interrupted by the presence of oligotrophic species from the poleward flow. The distribution of scores also showed similar values in the eddy, indicating similarity of the dinoflagellate assemblage in both structures.

Similar to eddies described in the California Current System and in the East Australian Current, the eddy found during the GALICIA-IX was embedded in water masses from very different origin and, therefore, could suffer diverse entrainment processes. Several authors (Simpson et al., 1984; Koblinsky et al., 1984; Simpson, 1984; Haury, 1984; Haury et al., 1986; Simpson et al., 1986; Simpson and Lynn, 1990) described the presence of a recurrent eddy $500 \mathrm{~km}$ off Point Conception, which is surrounded by cold waters of coastal origin and by warm waters of oceanic origin. In contrast to the eddy described here, this anticyclonic eddy is subjected to lateral entrainment from the surrounding warm oceanic waters and also from coastal waters (Simpson, 1984). In our case, the influx of upwelled waters from the coastal domain was not significant as it was clearly shown in the diatoms distribution off Cape Ortegal (Fig. 13c). There was only an exchange with the offshore nutrient-depleted waters at the northern quadrant of the eddy as the vertical distributions of the rest of microplankton populations show (Figs. 13d-13f). The vertical distributions of microplankton populations in the section across the eddy center (Figs. 11) confirm the absent of lateral entrainment. Therefore, the subsurface $\mathrm{Chl} a$ maximum at the eddy center is a remanent of the biological communities in the poleward flow. At this point, we can suggest that microplankton assemblage will decline, as lateral entrainment did not provide new nutrients. Such decline would be only possible if the eddy structure did not vanish. Similar mesoscale eddies in other regions persist for a few days to two weeks. Pingree $e$ t al. (1979) describe the evolution of phytoplankton growth in the cyclonic eddies formed in the Celtic shelf and indicate a time event of a few days. For the Gulf Stream cyclonic frontal eddies, characterized by a subsurface chlorophyll maximum on the nutricline, as the GALICIA-IX eddy, a persistence of 2 to 14 days was suggested by Yoder et al. (1981). Further studies are necessary in order to learn the time scale of this structure along our coasts. Another possibility, involving a 14-day time event, would be nutrient enrichment by convective overturn, similar to the East Australian Current cddics (Tranter et al., 1980 and Jeffrey and Hallegreff, 1980 and 1987). The high production found in a warm core was due to prolonged surface cooling and deep convective mixing, which conveyed previously unavailable nutrients to the surface eddy (Tranter $e t$ al., 1980 and Jeffrey and Hallegreff, 1980). However, the strong stratification and the deepening of the nutricline during GALICIA-IX cruise, prohibit this alternative eddy evolution.

The coastal domain in the northern coast was strongly affected by the eddy, in such a way that two different patterns of upwelling were observed east and west of Cape Ortegal. The anticyclonic eddy enhanced coastal upwelling in the adjacent coast (Yoder et al., 1981; Chavez et al., 1991), favoring phytoplankton development at the surface. West of the Cape the limiting nutrient was silicate, while east of the Cape, limitation can be imposed by nitrate or silicate, because limitation by silicate can be reached before total silicate 


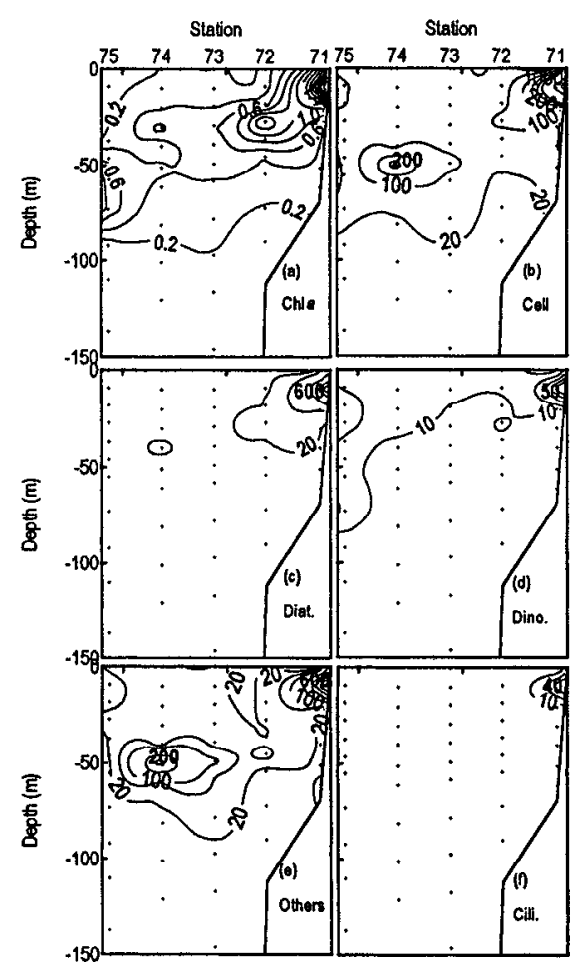

Figure 15. Vertical distributions of Chl $a$ (a); cell abundance (b); diatoms (c); dinoflagellates (d); others (e) and ciliate concentration (f) for cross-shelf transect 7 off Cape Vidio. Chl $a$ in $\mathrm{mg} \cdot \mathrm{m}^{-3}$ and cells concentrations in cells $\cdot l^{-1}\left(\times 10^{3}\right)$.

depletion (Levasseur and Therriault, 1987; Egge and Aksnes, 1992). Similar nutrient limitation was mentioned by Botas (1991) off Cape Peñas for an annual period. Confinement of biomass inshore of the upwelling front when coastal upwelling occurs coupled with a negative wind stress curl offshore was also described by Blanton et al. (1984). Minimum values of depth-integrated $\mathrm{Chl} a$ at stations on the frontal zone pointed out that limited entrainment was occurring between the continental shelf and the CTZ. East of Cape Ortegal, Chl $a$ distributions suggest a probable offshore transport following the position of the nutricline. This could be explained by a two-cell circulation pattern, similar to that described by Mooers et al. (1976) for the upwelling of Oregon. The downward motion around station 72 (Fig. 15a) must be weak, as the sinking phytoplankton patchiness basically consisted of a diatom community. The other three groups, dinoflagellates, small flagellates and ciliates can counteract this downward flow. Small and Menzies (1981) described another biomass core located offshore of the upwelling front. They found that this other core was sustained by the offshore cell, where nitrate was up to $5 \mu \mathrm{mol} \cdot \mathrm{kg}^{-1}$. In 
our case, we did not find another biomass core offshore of the front, probably due to poor-nutrient water masses in the oceanic cell.

\section{Summary and conclusions}

Previous studies of the Iberian CTZ were based on current meter records and satellite imagery (Pingree and Le Cann, 1990, 1992a, b; Haynes and Barton, 1990, 1991; Haynes et $a l ., 1993)$. However, there were a few observations focused on hydrography, phytoplankton species composition and primary production (Estrada, 1984; Varela et al., 1991; Fernández et al., 1991, 1993). The GALICIA-IX cruise allowed characterization of the CTZ in this part of the eastern boundary from a physical, chemical and biological (phytoplankton species distribution) perspective, during the transition from the upwelling to the downwelling season.

The most striking structures in the CTZ were a poleward-flowing high salinity water off the Rías Baixas and an anticyclonic eddy off Cape Ortegal. The poleward flow was characterized by low nutrient levels. Low cell numbers, with no diatoms and dinoflagellatedomination, were associated with the subsurface $\mathrm{Chl} a$ maximum found at the polewardHow domain.

The thermohaline and chemical fields suggest the eddy off Cape Ortegal was originated from the poleward-flowing high salinity water off Rios Baixas. Diatoms and dinoflagellates showed minimum cell numbers in the eddy. Origin of the eddy here was the same as swoddies but in our case the structure did not reach such deep levels of the water column. It was formed from the poleward flow of high salinity water which was interrupted by the upwelling center off Finisterre. Lower $\mathrm{Chl} a$ and higher nitrite concentrations in the eddy compared to the poleward flow suggest that the eddy is relatively older. Further research, with an adequate sampling strategy, is necessary to learn the development and lifetime of these surface structures in the area. Assuming 2 wk life-time, as frontal eddies in the Mid Atlantic Bight (Lee et al., 1981; Yoder et al., 1981), and considering that there was entrainment of nutrient-poor oceanic waters, phytoplankton populations in the eddy would probably decline before the eddy vanished.

The presence of these structures in the CTZ strongly affected the coastal regime. Along the west coast, outwelling from the Rías Baixas across the shelf break was impeded by the northward advance of the poleward flow. Prevention of export to the ocean of organic matter from the Rías Baixas and in situ produced, enhanced sedimentation and subsequent mineralization processes on the shelf. In a similar way, the coastal domain was controlled by the anticyclonic eddy in the Northern coast. Based on Chl $a$ and phytoplankton species distributions, we can suggest that the eddy also prevented cross-shelf exchange. Consequently, results from our work are in agreement with results from SFEP-I (Falkowski et al., 1988) and SEEP-II (Biscaye et al., 1994; Wirick, 1994) programs in the Mid Atlantic Bight, which have demonstrated that $<5 \%$ of the organic matter produced over the shelf is exported to the adjacent slope. However, it is clear that much work is need to quantify 
cross-shelf export of primary production in this upwelling system in different hydrographic situations.

Acknowledgments. The authors thank all participants in the GALICIA-IX cruise and the captain and crew of R/V Garcia del Cid for their support during the sampling program. Special thanks to R. Penín for help in drawing the figures and T. Rellán for help in data processing. Support for this work came from CICYT Grant No. 84-0068. A fellowship from the Spanish Ministerio de Educación y Ciencia allowed C.G.C. to carry out this work. X.A.A.-S. and F.F.P. were also supported for this work by the project EU-MAS2-CT93-65.

\section{REFERENCES}

Alvarez-Salgado, X. A., C. G. Castro, F. F. Pérez and F. Fraga. 1997. Nutrient mineralization patterns in shelf waters of the Western Iberian upwelling. Cont. Shelf Res., (submitted).

Alvarez-Salgado, X. A., G. Rosón, F. F. Pérez and Y. Pazos. 1993. Hydrographic variability off the Rías Baixas (NW Spain) during the upwelling season. J. Geophys. Res., 98(C8), 14447-14455.

Ambar, I. J. 1984. Seis meses de mediçoes de correntes, temperaturas e salinidades na vertente continental ao largo da costa alentejana. Relat. 'Tec., 1/84, Grupo de Oceanografia, Universidad de Lisboa, Lisbon, 47 pp.

1985. Seis meses de mediçoes de correntes, temperaturas e salinidades na vertente continental a 40 N. Relat. T'ec., 1/85, Grupo de Oceanografia, Universidad de Lisboa, Lisbon, 40 pp.

Ambar, I. J., A. F. G. Fiúza, T. Boyd and R. Frouin. 1984. Observations of a warm oceanic current flowing northward along the coasts of Portugal and Spain during November-December, 1983. EOS Trans. Am. Geophys. Union, 67(44), 1054.

Bakun, A. 1973. Coastal upwelling indices, west coast of North America, 1946-71, NOAA Tech. Rep. NMFS-671, 103 pp.

Bakun, A. and C. S. Nelson. 1991. The seasonal cycle of wind-stress curl in subtropical eastern boundary current regions. J. Phys. Oceanogr., 21, 1815-1834.

Biscaye, P. E., C. N. Flagg and P. Falkowski. 1994. The Shelf Edge Exchange Processes experiment, SEEP-II: an introduction to hypotheses, results and conclusions. Deep-Sea Res., 41, 231-252.

Blanton, J. O., K. R. Tenore, F. F. Castillejo, L. P. Atkinson, F. B. Schwing and A. Lavin. 1987. The relationship of upwelling to mussel production in the rías on the western coast of Spain. J. Mar. Res., 45, 497-511.

Blanton, J. O., L. P. Atkinson, F. Fernández de Castillejo and A. L. Montero. 1984. Coastal upwelling off the Rias Bajas, Galicia, Northwest Spain I: Hydrographic studies. Rapp. P.-v. Reun. Cons. Int. Explor. Mer., 183, 79-90.

Botas, J. A. 1991. Distribución de los nutrientes inorgánicos en el Cantábrico Central: Efecto de las masas de agua y de la actividad biológica. PhD Thesis, University of Oviedo, Spain, $255 \mathrm{pp}$.

Bray, N. A. and C. L. Greengrove. 1993. Circulation over the shelf and slope off Northern California. J. Geophys. Res., 98(C10), 18119-18145.

Brockmann, C. E., E. Farbach, A. Huyer and R. L. Smith. 1980. The poleward undercurrent along the Peru coast: 5 to 15S. Deep-Sea Res., 27A, 847-856.

Broecker, W. S. 1974. "NO," a conservative water-mass tracer. Earth Planet. Sci. Letts, 23, 100-107.

Chavez, F. P., R. T. Barber, P. M. Kosro, A. Huyer, S. R. Ramp, T. P. Stanton and B. Rojas de Mendiola. 1991. Horizontal transport and the distribution of nutrients in the coastal transition zone off northern California: Effects of primary production, phytoplankton biomass and species composition. J. Geophys. Res., 96(C8), 14833-14848.

Dickson, R. R. and D. G. Hughes. 1981. Satellite evidence of mesoscale eddy activity over the Biscay abyssal plain. Oceanol. Acta, 4, 43-46. 
Egge, J. K. and D. L. Aksnes. 1992. Silicate as regulating nutrient in phytoplankton competition. Mar. Ecol. Prog. Ser., 83, 281-289.

Estrada, M. 1984. Phytoplankton distribution and composition off the coast of Galicia (northwest of Spain). J. Plank. Res., 6, 417-434.

Falkowski, P. G., C. N. Flagg, G. T. Rowe, T. E. Whitledge and W. G. Harrison. 1988. The fate of spring bloom: export or oxidation? Cont. Shelf Res., 8, 457-484.

Fernández, E., A. Bode, A. Botas and R. Anadón. 1991. Microplankton assemblages associated with saline fronts during a spring bloom in the central Cantabrian Sea: differences in trophic structure between water bodies. J. Plank. Res., 13, 1239-1256.

Fernández, E., J. Cabal, J. L. Acuña, A. Bode, A. Botas and C. García-Soto. 1993. Plankton distributions across a slope current-induced front in the southern Bay of Biscay. J. Plank. Res., 15, 619-641.

Fiúza, A. F. G. 1982. The Portuguese coastal upwelling system, in Actual problems in oceanography in Portugal, Junta Nacional de Investigaçao Científica e Tecnológica. Lisbon, 259, 46-70.

- 1983. Upwelling Patterns of Portugal in Coastal Upwelling, E. Suess and J. Thiede, eds., Plenum Press, New York, 85-97.

1984. Hidrologia e dinâmica das aguas costeiras de Portugal. Ph D. thesis, Univ. of Lisbon, $294 \mathrm{pp}$

Fiúza, A. F. G., M. E. de Macedo and M. R. Guerreiro. 1982. Climatological space and time variation of the Portuguese coastal upwelling. Oceanol. Acta, 5, 31-40.

Fraga, F. 1981. Upwelling off the Galician coast, Northwest Spain in Coastal Upwelling. Coastal and Estuarine Sci., Vol. 1, F. A. Richards, ed., AGU, Washington, D.C., 176-182.

Fraga, F., C. Mouriño and M. Manríquez. 1982. Las masas de agua en la costa de Galicia: junio-octubre. Res. Exp. Cient., 10, 51-77.

Frouin, R., A. F. G. Fiúza, I. Ambar and T. J. Boyd. 1990. Observations of a poleward surface current off the coasts of Portugal and Spain during winter. J. Geophys. Res., 95, 679-691.

Fruchaud, B. 1975. Etude hydrologique et variations saisonnires dans le Proche-Atlantique en 1972. Rapp. Sci. CNEXO, 20.

Fruchaud-Laparra, B., J. Le Floch, J. Y. Le Tareau and A. Tanguy. 1976a. Etude hydrologique et variations saisonnires dans le Proche-Atlantique en 1973. Rapp. Sci. CNEXO, 26.

1976b. Etude hydrologique et variations saisonnires dans le Proche-Atlantique en 1974. Rapp. Sci. CNEXO, 30.

Hansen, H. P. and K. Grasshoff. 1983. Automated Chemical Analysis in Methods of Seawater Analysis, K. Grasshoff, M. Ehrardt, and K. Kremling, eds., Verlag Chemie, Weinheim, 347-395.

Haury, L. R. 1984. An offshore eddy in the California Current System, Part IV: Plankton distributions. Prog. Oceanogr., 13, 95-111.

Haury, L. R., J. J. Simpson, J. Peláez, C. J. Koblinsky and D. Wiesenhahn. 1986. Biological consequences of a recurrent eddy off Point Conception, California. J. Geophys. Res., 9I(C11), $12937-12956$.

Haynes, R. and E. D. Barton. 1990. A poleward flow along the Atlantic coast of the Iberian Peninsula. J. Geophys. Res., 95(C7), 11425-11441.

1991. Lagrangian observations in the Iberian Coastal Transition Zone. J. Geophys. Res., 96(C8), 14731-14741.

Haynes, R., E. D. Barton and I. Pilling. 1993. Development, persistence and variability of upwelling filaments off the Atlantic coast of the Iberian Peninsula. J. Geophys. Res., 98(C12), 22681-22692.

Hidy, G. M. 1972. A view of recent air-sea interaction research. Bull. Am. Meteorol. Soc., 53, 1083-1102. 
Huyer, A. 1980. The offshore structure and subsurface expression of sea level variations off Peru, 1976-1977. J. Phys. Oceanogr., 10, 1755-1768.

Jeffrey, S. W. and G. M. Hallegraeff. 1980. Studies of phytoplankton species and photosynthetic pigments in a warm core eddy of the east Australian Current. I. Summer populations. Mar. Ecol. Prog. Ser., 3, 285-294.

1987. Phytoplankton pigments, species and light climate in a complex warm-core eddy of the East Australian Current. Deep-Sea Res., 34, 649-673.

Kautsky, H., K. P. Koltermann and G. Prahm. 1977. Circulation in the Canary Current upwelling region off Cabo Bojador in August 1972. Deep Sea Res., 22, 547-557.

Koblinsky, C. J., J. J. Simspon, and T. D. Dickey. 1984. An offshore eddy in the California Current system, II Surface manifestation. Prog. Oceanogr., 13, 51-69.

Largier, J. L., B. A. Magnell and C. D. Winant. 1993. Subtidal circulation over the Northern California Shelf. J. Geophys. Res., 98(C10), 18147-18179.

Lee, T. N., L. P. Atkinson and R. Legeckis. 1981. Observations of a Gulf Stream frontal eddy on the Georgia continental shelf, April 1977. Deep-Sea Res., 28, 347-378.

Levasseur, M. E. and J. C. Therriault. 1987. Phytoplankton biomass and nutrient dynamics in a tidally induced upwelling: the role of the $\mathrm{NO}_{3}: \mathrm{SiO}_{4}$ ratio. Mar. Ecol. Prog. Ser., 39, 87-97.

López-Jamar, E., R. M. Cal, G. González, R. B. Hanson, J. Rey, G. Santiago and K. R. Tenore. 1992. Upwelling and outwelling effects of the benthic regime of the continental shelf off Galicia, NW Spain. J. Mar. Res., 50, 465-488.

Lynn, R. J. and J. J. Simpson. 1987. The California Current System: The seasonal variability of its physical characteristics. J. Geophys. Res., 92(C12), 12947-12966.

Malone, T. C., T. S. Hopkins, P. G. Falkowski, T. E. Whitledge. 1983. Production and transport of phytoplankton biomass over the continental shelf of the New York Bight. Cont. Shelf. Res., 1, 305-337.

McClain, C. R., Shenn-Yu Chao, L. P. Atkinson, J. O. Blanton and F. F. de Castillejo. 1986. Wind-driven upwelling in the vicinity of Cape Finisterre. J. Geophys. Res., 91(C7), 8470-8486.

Meincke, J., G. Siedler and W. Zenk. 1975. Some current observations near the continental slope off Portugal. Meteor Forsch.-Ergebnisse, A (16), 15-22.

Minas, H. J., T. T. Packard, M. Minas and B. Coste. 1982. An analysis of the production-regeneration system in the coastal upwelling area off NW Africa based on oxygen, nitrate and ammonium distributions. J. Mar. Res., 40, 615-641.

Mittelstaedt, E. 1983. The upwelling area off Northwest Africa-a description of phenomena related to coastal upwelling. Prog. Oceanogr., 12, 307-331.

1991. The ocean boundary along the Northwest African coast: Circulation and oceanographic properties at the sea surface. Prog. Oceanogr., 26, 307-355.

Monteiro, J. H., F. G. Abrantes, J. M. Alveirinho-Días and L. C. Gaspar. 1983. Upwelling records in recent sediments from southern Portugal: a reconnaissance survey, in Coastal Upwelling, E. Suess and J. Thiede, eds., Plenum, London, 145-162.

Mooers, C. N. K., C. A. Collins and R. L. Smith. 1976. The dynamics structure of the frontal zone in the coastal upwelling region off Oregon. J. Phys. Oceanogr., 6, 3-21.

Mouriño, C. and F. Fraga. 1985. Determinación de nitratos en agua de mar. Invest. Pesq., 49, 81-96.

Pérez, F. F., C. Mouriño, F. Fraga, A. F. Ríos. 1993. Displacement of water masses and remineralization rates off the Iberian Peninsula by nutrient anomalies. J. Mar. Rcs., 51, 869-892.

Pingree, R. D. 1994. Winter warming in the southern Bay of Biscay and Lagrangian eddy kinematics from a deep-drogued argos buoy. J. Mar. Biol. Ass. U.K., 74, 107-128.

1979. Baroclinic eddies bordering the Celtic Sea in late summer. J. Mar. Biol. Assoc. U.K., 59, $689-698$. 
Pingree, R. D., Holligan, P. M. and G. T. Mardell. 1979. Phytoplankton growth and cyclonic eddies. Nature, 278, 245-247.

Pingree, R. D. and B. Le Cann. 1990. Structure, strength and seasonality of the slope currents in the Bay of Biscay region. J. Mar. Biol. Assoc. U.K., 70, 857-885.

1992a. Anticyclonic eddy X91 in the southern Bay of Biscay, May 1991 to February 1992. J. Geophys. Res., 97(C9), 14353-14367.

1992b. Three anticyclonic Slope Water Oceanic eDDIES (SWODDIES) in the Southern Bay of Biscay in 1990. Deep-Sea Res., 39, 1147-1175.

Ríos, A. F., F. F. Pérez and F. Fraga. 1992. Water masses in upper and middle North Atlantic Ocean east of the Azores. Deep Sea Res., 39, 645-658.

Simpson, J. J. 1984. An offshore eddy in the California Current System. Part III: Chemical Structure. Prog. Oceanogr., 13, 71-93.

Simpson, J. J., T. D. Dickey, and C. J. Koblinsky. 1984. An offshore eddy in the California Current System. Part I: Interior Dynamics. Prog. Oceanogr., 13, 5-49.

Simpson, J. J., C. J. Koblinsky, J. Pelaez, L. R. Haury and D. Wiesenhahn. 1986. Temperature-plant pigment-optical relations in a recurrent offshore mesoscale eddy near Point Conception, California. J. Geophys. Res., 91, 12919-12936.

Simpson, J. J. and R. J. Lynn. 1990. A mesoscale eddy dipole in the offshore California Current. J. Geophys. Res., 95, 13009-13022.

Small, L. F. and D. W. Menzies. 1981. Patterns of primary productivity and biomass in a coastal upwelling region. Deep-Sea Res., 28A, 123-149.

Sverdup, H. U. and R. H. Fleming. 1941. The waters off southern California March to July 1937, Bull. of the Scripps Inst. of Oceanogr., Univ. of Calif., La Jolla, 4, 261-378.

Swallow, J. C., W. J. Gould and P. M. Saunders. 1977. Evidence for a poleward eastern boundary current in the North Atlantic Ocean. ICES hydrography committee, C. M. 1977/c:32, 21 pp.

Tenore, K. R. and 18 authors. 1995. Fisheries and oceanography off Galicia, NW Spain: Mesoscale spatial and temporal changes in physical processes and resultant patterns of biological productivity. J. Geophys. Res., 100, 10943-10966.

Tilstone, G. H., F. G. Figueiras and F. Fraga. 1994. Upwelling-downwelling sequences in the generation of red tides in a coastal upwelling system. Mar. Ecol. Prog. Ser., 112, 241-253.

Tranter, D. J., R. R. Parker and G. R. Cresswell. 1980. Are warm-core eddies unproductive? Nature, $284,540-542$.

UNESCO. 1981. Tenth report of the joint panel on oceanographic tables and standards. UNESCO Tech. Pap. in Mar. Sci., 36, 40 pp.

Utermöhl, H. 1958. Zur Vervollkommnung der quantitativen Phytoplankton-Methodik. Mitt. Int. Ver, Theor. Angew. Limnol., 9, 1-38.

Varela, M., G. Díaz del Río, M. T. Alvarez-Ossorio and E. Costas. 1991. Factors controlling phytoplankton size class distribution in the upwelling area of the Galician continental shelf (NW Spain). Sci. Mar., 55, 505-518.

Wirick, C. D. 1994. Exchange of phytoplankton across the continental shelf-slope boundary of the Middle Atlantic Bight during spring 1988. Deep-Sea Res., 41, 391-410.

Wooster, W. S., A. Bakun and D. R. McClain. 1976. The seasonal upwelling cycle along the eastern boundary of the North Atlantic. J. Mar. Res., 34, 131-141.

Wooster, W. S. and J. L. Reid, Jr. 1963. Eastern boundary currents, in The Sea, Vol. 2, M. N. Hill, ed. Wiley Interscience, 253-280.

Wyrtki, K., L. Magaard and J. Hager. 1976. Eddy energy in the oceans. J. Geophys. Res., 81, 2641-2646. 
Yentsch, C. S. and D. W. Menzel. 1963. A method for the determination of phytoplankton chlorophyll and phaeophytin by fluorescence. Deep-Sea Res., 10, 221-231.

Yoder, J. A., L. P. Atkinson, N. L. Lee, H. H. Kim and C. R. McClain. 1981. Role of Gulf Stream frontal eddies in forming phytoplankton patches on the outher southeastern shelf. Limnol. Oceanogr., 26, 1103-1110. 